\title{
Denosumab for effective tumor size reduction in patients with giant cell tumors of the bone: a systematic review and meta-analysis
}

Josef Yayan ( $\square$ josef.yayan@hotmail.com )

Universitat Witten/Herdecke GERMANY

Research article

Keywords: Denosumab, Giant cell tumor of the bone, Osteoclastoma, Outcome, Meta-analysis

Posted Date: July 3rd, 2019

DOl: https://doi.org/10.21203/rs.2.10979/v1

License: (c) (i) This work is licensed under a Creative Commons Attribution 4.0 International License.

Read Full License

Version of Record: A version of this preprint was published at Cancer Control on July 1st, 2020. See the published version at https://doi.org/10.1177/1073274820934822. 


\section{Abstract}

Background Denosumab is a human monoclonal antibody that is used in the successful treatment of giant cell bone tumors. These tumors are rare and, in principle, benign, but they are highly aggressive, locally advanced, and osteolytic bone tumors that can metastasize to the lungs. Denosumab is an effective treatment when these tumors cannot be surgically removed or when surgical resection is likely to lead to severe morbidity (e.g., loss of limbs or joints). The aim of this systematic review and metaanalysis was to investigate the patients with giant cell bone tumors who experienced tumor progression during treatment with denosumab and to compare them with patients who experienced reduction of their giant cell bone tumors during treatment with denosumab. Methods The Embase, Cochrane Library, and MEDLINE/PubMed databases were searched until February 28, 2018 for trials reporting the efficacy and safety of denosumab in patients with giant cell bone tumors. Results Thirty-three studies were reviewed, involving a total of 350 patients who had giant cell bone tumors and were treated with denosumab. Of the 33 studies, $67 \%$ of the patients were from open-label phase II studies, $27 \%$ from case series, and $6 \%$ from case reports. The response rate for denosumab as a treatment for giant cell bone tumors was $95.3 \%$, with statistical significance $(P<0.0001)$. Osteonecrosis of the jaw was statistically the most common adverse event for denosumab treatment in open-label phase II studies $(P<0.0001)$. No treatment-related deaths occurred in the reviewed studies. Conclusion Cumulative evidence supports the addition of surgery to optimal medical therapy with denosumab to reduce tumor size, clinical symptoms, and mortality among patients with giant cell bone tumors.

\section{Background}

Denosumab was first introduced in the year 2010 for the treatment of osteoporosis and now used at a high dosage to prevent skeletal-related complications in adults with solid bone metastases [1].

Denosumab can also be used to treat giant cell bone tumors (GCBT) if they cannot be surgically removed [2].Denosumab binds to and inhibits the receptor activator of nuclear factor kappa-B ligand (RANKL), thereby reducing the formation and activation of osteoclasts [3]. In turn, this decreases the loss of bone mass, which reduces the likelihood of bone fractures and other serious bone complications $[4,5]$. Denosumab treatment also prevents further tumor growth [6]. However, the desired effects of denosumab that curb the spread of GCBT are also accompanied by undesirable side effects [7-10].

The approval of denosumab for use in the treatment of GCBT is based on positive results from two openlabel phase II studies on patients whose tumors were either non-resectable or for whom surgery was associated with severe morbidity $[11,12]$. Despite being a local, highly aggressive tumor, a GCBT is usually benign; however, it has metastatic potential for the lungs, and different chemotherapy regimens can have unfavorable outcomes [13]. The histogenesis of GCBT is still unknown, and no correlation has yet been found with either histological or clinical presentations [13]. For this reason, many investigators consider its prognosis unpredictable. 
The aim of this meta-analysis was to review the benefits and risks involved in the use of denosumab for patients who had GCBT with tumor progression and to compare these patients with patients who showed tumor regression, according to the results of previously published studies. In other words, the meta-analysis was designed to examine how many patients with GCBT have benefited from the introduction of denosumab and to determine whether the benefits have been greater than the potential risks. This work provides the first critical evaluation of denosumab as a treatment for giant cell bone tumors.

\section{Methods}

\section{Ethics statement}

No ethical approval from the Ethics Committee of Witten/Herdecke University was required because this work was a literature search.

\section{Patients}

After an intensive literature search for trials in Embase, the Cochrane Central Register of Controlled Trials (CENTRAL), and MEDLINE/PubMed until February 28, 2018, the efficacy and safety of denosumab as a monoclonal antibody with a recent approval extension were determined in the patients with GCBT with tumor progression and compared with the efficacy and safety of denosumab observed in patients with tumor regression. For this present evaluation, the age and gender of the subjects were assessed from the results of previously published studies of patients with GCBT. The tool "clinicaltrials.gov" was also checked for studies about denosumab treatment of GCBT.

\section{Endpoints of this review}

This meta-analysis considered the following nine events as relevant to the definitions of the endpoints of this systematic review: pulmonary metastases, tumor progression, secondary tumor development, GCBT death, death from other cancers, treatment-related death, rejection of treatment, noncompliance, and loss of follow-up. The following seven endpoints were considered relevant to the assessment of the effects of treatment with denosumab: disease-free survival, local recurrence of GCBT, treatment failure of denosumab, adverse effects of denosumab, recurrence-free survival, survival without tumor progression, and overall survival.

\section{Cohort 1: Tumor progression during treatment with denosumab}


Cohort 1 included all the patients with GCBT who had tumor progression, with possible lung metastases, during treatment with denosumab. Another criterion was treatment failure with denosumab.

\section{Cohort 2: Tumor controlled by denosumab}

Cohort 2 included all patients with GCBT who had tumor regression during treatment with denosumab. Cohort 2 was used as the comparison group.

\section{Data collection}

Suitable studies that included patients with GCBT who were undergoing drug treatment with denosumab were searched by entering the search terms "denosumab" and "giant cell tumors of the bone" into the search consoles of Embase, CENTRAL, and MEDLINE/PubMed, followed by the filters "humans" and "text availability in abstract." The systematic review and meta-analysis were performed according to the recommendations of the Preferred Reporting Items for Systematic Reviews and Meta-Analyses [14].

\section{Study choice}

No randomized controlled trials for denosumab treatment of GCBT were found in the literature. Therefore, this review included all the non-randomized, uncontrolled, and open-label phase II studies, as well as case series and case reports, concerned with the efficacy of denosumab in patients with GCBT. The selection criteria for the studies used in the analysis were as follows: the study should report on (a) the outcome of the treatment with denosumab in addition to the demographic data, (b) the location of the tumor, (c) the surgical treatment, (d) the adverse reactions to denosumab, (e) the duration of treatment with denosumab, and (f) the follow-up time. The studies were evaluated after they were classified according to the study design. Within each category of the study design, the data were compared between the cohort 1 and cohort 2. Published studies were excluded if the effectiveness of the administration of denosumab in patients with GCBT was not stated.

\section{Definition of giant cell tumor of the bone}

A giant cell bone tumor is a rare tumor that is often found in the epiphysis of the long bone. It is an aggressively growing tumor but is considered benign [15]. Raised radiographic findings of a cystic, juxtaarticular, non-reactive mass lead to a biopsy. After tumor removal, a high risk of relapse remains [16]. In the present study, GCBT were identified and referred to as a primary or recurrent tumors, in addition to being recurrently unresectable [17]. 
GCBT occur mainly in the knee joint area, in the proximal humerus, and in the distal radius. For the sake of brevity, these areas were identified as the lower and upper extremities in the present study [18]. Other less frequent localizations also considered here include the skull, the spine, the trunk, the pelvis, and the sacrum [19-22]. Metastases to the lungs are less common but have been included in the present study [23]. GCBT usually occur in patients between 20 and 40 years of age [24]; in the present study, age is expressed as the mean in years in the demographic data of the patients. Bone-destroying GCBT often cause fractures, which are reported as being among the unwanted side effects of denosumab $[25,26]$.

\section{Radiological imaging}

A giant cell bone tumor was initially diagnosed upon detecting osteolytic areas in X-ray radiographic images. Thereafter, computerized tomography (CT) and magnetic resonance imaging (MRI) were performed on the patients with GCBT [27].

\section{Pathohistology}

The radiographic findings of a cystic [28], juxta-articular [29], and non-reactive mass led to a biopsy [30]. The diagnosis of a GCBT was made by examining the biopsy tissue under a microscope after hematoxylin-eosin staining. A GCBT showed very characteristic multinuclear osteoclast-like giant cells, and the actual tumor cells were similar to mesenchymal mononuclear fibroblast-like cells [31].

\section{Characteristics of denosumab}

The human monoclonal antibody denosumab was used to treat the GCBT in all the patients in this study if the tumors could not be surgically removed or if surgical resection was likely to lead to severe frailty (e.g., loss of limbs). The aim of denosumab treatment was to reduce the activity of osteoclasts, and thus bone resorption, in all the patients with GCBT in this investigation [32, 33].

\section{Dosage and method of denosumab administration}

Denosumab was administered as a subcutaneous injection of $120 \mathrm{mg}$ in the thigh, the abdominal region, or the upper arm in all the participants. The drug was injected every four weeks, with additional 
$120 \mathrm{mg}$ single doses on days 8 and 15 of the first month of treatment [34]. The second cycle started on day 29 or 4 weeks after day 15. The patients who underwent a complete resection of the GCBT also received an additional six months of denosumab treatment after surgery. When an additional surgical intervention was required for the patients whose tumor showed incomplete regression, denosumab was used as a neoadjuvant treatment. The goal of this neoadjuvant therapy was to achieve an improved starting situation for the operation, to make the disease operable, or to forgo mutilating surgery. The time of denosumab application before and after surgery or as a neoadjuvant treatment was addressed in the evaluations in this study.

All patients in this study, except those with existing hypercalcemia, also had to receive at least $500 \mathrm{mg}$ of calcium and $400 \mathrm{IU}$ of vitamin D per day [35]. Existing hypocalcemia had to be corrected before the start of therapy. Hypocalcemia could occur at any time during therapy, requiring regular control of calcium levels [36]. Hypocalcemia was considered one of the side effects of denosumab in this study. The duration of denosumab treatment and follow-up in patients with GCBT was determined individually by the treating physicians, depending on the drug response and tolerability of the treated patients. When this information was indicated in the examined studies, data on the duration of denosumab therapy and follow-up were collected.

\section{Definition of therapy success with denosumab}

The objective response rate of GCBT was expressed based on the best response rate to denosumab, as determined by MRI or CT in the control record in the follow-up at an interval of six months. Response was determined by radiological measurement of the longest diameter of the GCBT and comparison to the measurement obtained at the initial MRI or CT examination. The disappearance of all GCBT was considered a complete response, disappearance by at least $30 \%$ in diameter was considered a partial response, the same tumor size was considered a stable disease, and an increase of $20 \%$ in tumor size was considered progression of the disease, according to the modified Response Evaluation Criteria in Solid Tumors [37]. GCBT were detected using ${ }^{18} \mathrm{~F}$-fluorodeoxyglucose, a radioactively labeled tracer, by recording the metabolic processes with positron emission tomography, according to the modified European Organization for Research and Treatment of Cancer [38].

\section{Definition of treatment failure with denosumab}

In this review, treatment failure with denosumab in GCBT was established when radiology or histology demonstrated local recurrences of GCBT, when GCBT progressed by metastasis to the lungs, or when patients had progression $\geq 20 \%$ during denosumab treatment of GCBT [37]. 


\section{Side effects of denosumab}

The evaluation of the side effects of denosumab served to establish the possible connection with the progression of GCBT. The comparison of the frequency of side effects of denosumab reported here refers to the comparison of the two cohorts and is not a frequency indication of the side effects of denosumab in general. The common side effects of denosumab considered in this study were hypocalcemia, hypophosphatemia, osteonecrosis of the jaw, pain extremities, and skin rash [39, 40, 41]. Rare side effects, such as anemia, headache, hypercalcemia, hyperparathyroidism, parathyroid adenoma, pathological bone fracture, and peripheral neuropathy, as well as serious adverse events - which could occur at any time-were also identified in this study [42]. The severe adverse events that were described as life-threatening during treatment with denosumab for GCBT included the need for life-saving interventions, a high risk of death, and the need for hospitalization, as indicated by the Common Terminology Criteria for Adverse Events developed by the US National Cancer Institute [43].

\section{Types of surgery}

\section{Amputation and joint or prosthesis replacement}

Left untreated, GCBT can lead to the complete destruction of the affected bone, deformities, joint disorders, and even amputations. The frequency of amputation and joint or prosthesis replacement was examined among the operative measures in this study [44].

\section{Curettage}

The traditional surgical treatment for GCBT is intralesional aggressive curettage, which involves using an additional mechanical high-speed milling cutter, followed by the application of bone cement to fill the surgical defect. This cement could be replaced with bone after one or two years if the GCBT shows no recurrence. In addition, chemically toxic substances (e.g., alcohol or phenol) are often added to kill the remaining GCBT cells [45].

\section{En bloc resection}

A high probability of recurrence of GCBT inevitably leads to a radical surgical procedure in the form of en bloc resection, in which the actual GCBT, as well as the affected neighboring tissue or the lymph 
node, are removed in one piece [46].

\section{En bloc excision}

A tissue part that has been affected by GCBT is removed as an en bloc excision in some cases [46]. In the most favorable cases, the surgeon can perform a marginal excision to remove the GCBT, along with the surrounding margin of the tissue [48].

\section{Spondylectomy}

Rare localizations in the spine and sacral areas are treated with the difficult surgical procedure of spondylectomy [49]. Spondylectomy is an operative removal of one or more vertebral bodies, with subsequent replacement and stabilization of the spinal column section.

\section{No surgery}

The use of denosumab can circumvent an operation in the very best of cases.

\section{Embolization}

Preoperative radiologic-interventional elective embolization is sometimes useful to control a difficult GCBT and is conducted by administering liquid plastics via a catheter into the patient's artery. This procedure was also investigated in this study [50].

\section{Mortality}

The number of deaths among denosumab-treated patients with GCBT was surveyed after a review of the studies in this analysis. 
The non-randomized, uncontrolled, and open-label phase II studies were evaluated and validated using the risk assessment tool for non-randomized studies (RoBANS) [51]. The studies were evaluated based on the following three characteristics: (a) high risk of bias, (b) low risk of bias, and (c) unclear risk of bias. RoBANS covers aspects such as participant selection, confounding variables, intervention measurement, blinding of the outcome assessment, incomplete data results, and selective outcome reporting.

\section{For case series}

The Joanna Briggs Institute is an international membership-based research and development organization within the Faculty of Health Sciences of the University of Adelaide in Australia [52]. The institute developed a critical appraisal tool for systematic reviews, and this tool was used to evaluate the case series in this work [53]. Using 10 questions, the tool rates each case series with the answers "yes," "no," or "unclear," where "yes" corresponds to a low risk of bias, "no" to a high risk of bias, and "unclear" to an unclear risk of bias [53]. The 10 questions focus on the following: clear criteria for inclusion in the case series, measurement of the condition in a standard and reliable way for all the participants included in the case series, use of valid methods for the identification of the condition of all the participants included in the case series, consecutive inclusion of the participants in the case series, complete inclusion of the participants, clear reporting of the participants' demographics in the study, clear reporting of the participants' clinical information, clear reporting of the outcomes or follow-up results of the cases, clear reporting of the demographic information of the presenting clinics, and the use of appropriate statistical analysis.

\section{For case reports}

The evaluation of the case reports also used the critical appraisal tool of the Joanna Briggs Institute [54]. This checklist for the case reports consists of eight questions $[54,55]$. The questions focus on the assessment methods; the patients' demographic characteristics, history, current clinical condition, and post-intervention clinical condition; the treatment procedure; adverse events; and the case report's takeaway lessons. These case report questions are rated either "yes" for a low risk of bias, "no" for a high risk of bias, or "unclear" for an unclear risk of bias.

\section{Statistical analysis}

The numbers studied in proportions were expressed as percentages (\%). Mean and standard deviation (SD) were used to calculate the mean age, the duration of treatment, and the follow-up of the 
patients in the analysis of GCBT therapy with denosumab [56]. For the evaluation of the results in this systematic review, a $P$ value of $<0.05$ was determined to be statistically significant.

A Mann-Whitney U test for unpaired data of two samples was used to compare age differences, duration of treatment, and follow-up time [57]. Chi-square analysis was used to examine the gender difference between the published studies, classification of tumors, time of administration of denosumab, localization of tumors, course of treatment, outcome of treatment, side effects of denosumab, surgery procedures, and embolization [58]. A confidence interval ( $\mathrm{Cl})$ of proportions was computed from the observed data for the comparison of the number of patients in cohort 1 and cohort 2, as well as the number of patients according to the study design [59].

\section{Results}

Entry of the search criteria into the search consoles of Embase, CENTRAL, and MEDLINE/PubMed retrieved a total of 298 human trials for the period until February 28, 2018 (Fig. 1). A critical review of these published studies identified 33 studies that met the inclusion criteria for the present meta-analysis (Table 1) [11, 12, 60-90]. The "clinicaltrials.gov" showed 7 ongoing studies about denosumab in the treatment of GCBT. The majority of the studies examined for this meta-analysis were case reports, case series, and non-randomized, uncontrolled, and open-label phase II studies (Fig. 2). The evaluation of these eligible studies yielded a total of 350 patients with GCBT who underwent drug treatment with denosumab. Of these, $34(9.7 \%, 95 \% \mathrm{Cl} 6.6 \%-12.8 \%)$ were in cohort 1 and $316(90.3 \%, 95 \% \mathrm{Cl} 87.2 \%-$ $93.4 \%$ ) were in cohort 2 across all study types. However, most of the patients in this meta-analysis were from the non-randomized, uncontrolled, and open-label phase II studies (234 patients: $66.9 \%, 95 \% \mathrm{Cl}$ $62.0 \%-71.8 \%$ ), followed by the case series (93 patients: $26.6 \%, 95 \% \mathrm{Cl} 22.0 \%-31.2 \%$ ) and then the case reports (23 patients: 6.6\%, 95\% Cl 4.0\%-9.2\%) (Table 2) (Fig. 2).

After evaluation of the data, sex assignment was not possible for the study by Thomas et al. [11] or for the study by Chawla et al. [12], for a total of 160 patients (11 in cohort 1, 149 in cohort 2) (Table 2). Despite this fact, a narrow majority of the included study participants with GCBT in cohort $1(41.2 \%)$ and in cohort $2(26.9 \%)$ consisted of women; however, the difference was not statistically significant (Table 2). Fehler bei der ÜbersetzungThe classical age of onset of GCBT in these study participants was mainly in the second decade of life, with a median age of 29 in cohort 1 and 29 in cohort 2, followed by the third decade of life (Table 2). The age and gender distributions were statistically unremarkable when compared with that in cohort 1 and cohort 2 across all study types (Table 2). The duration of treatment with denosumab and the follow-up time were not statistically different between cohort 1 and cohort 2 (Table 2). The classification of tumors in primary and recurrent tumors had statistical significance only in the case reports (Table 2).

All the subjects in the actual studies received denosumab as a single subcutaneous injection in the thigh, the abdominal region, or the upper arm at the recommended dose of $120 \mathrm{mg}$ at regularly prescribed 
intervals of four weeks and in additional doses of $120 \mathrm{mg}$ on days 8 and 15 of the first month of treatment. The second cycle started on day 29 or 4 weeks after day 15 . ForFehler bei der ÜbersetzungForFor the treatment of GCBT in these published studies, denosumab was given as a neoadjuvant therapy in many cases, with statistical significance in open-label phase II studies (Table 2). The administration of denosumab pre- and postoperatively, or only postoperatively, did not have a statistical impact (Table 2).

The preferred body localization of GCBT was statistically significant and was mainly in the sacral bone in cohort 1 and in lower limb in cohort 2 of the open-label phase II studies, whereas in the case series and case reports, differences in body localization were not statistically significant (Table 2). Progression of the tumor disease was statistically more frequent in the open-label phase II studies and case reports (Table 2). Non-response to treatment with denosumab and an increased incidence of recurrence with denosumab were statistically more frequent in the case series (Table 2). Only in the case series could tumor shrinkage or even tumor freedom be statistically recorded in most patients in cohort 2 (Table 2). Finally, the evaluation of this study showed a response rate of at least $95.3 \%$ of the tumor after treatment with denosumab in the open-label phase II studies and this rate was statistically significant $(P<0.0001)$ (Table 2).

Osteonecrosis of the jaw was frequently reported as relatively common in patients treated with denosumab in cohort 1 in the open-label phase II studies, and this had statistical relevance $(P<0.0001)$ (Table 3). Curettage was the most common type of surgery in patients with GCBT in the case series, followed by en bloc resection, but the difference was not statistically significant (Table 4). The GCBT embolization procedure was used only among a small number of the patients in this study (Table 4). The studies did not report any deaths from either denosumab treatment or GCBT (Table 2).

The evaluation of the open-label phase II studies generally showed a low risk of bias (Fig. 3). By contrast, a high risk of bias was detected in open-label phase II studies due to insufficient blinding of the outcome assessment, insufficient handling of incomplete outcome data, and selective outcome reporting (Fig. 3). The quality assessment for the case series also generally showed a low risk of bias (Fig. 4). Some case series showed a high risk of bias for statistical analysis, insufficient reporting of the following results, and incomplete inclusion of the participants (Fig. 4). The overall assessment of the study quality for the case reports showed a low risk of bias (Fig. 5). Only one study had an increased risk of bias due to the unclear description of the post-interventional clinical situation of a patient in the case reports (Fig. 5).

\section{Discussion}

The results of this meta-analysis showed that denosumab can be an effective therapy for the treatment of patients with GCBT. The published studies analyzed in this review show evidence of the efficacy of denosumab in this group of patients, and the drug has therefore made a good impression on medical profession in general. The published studies also indicate the treatment failure of denosumab when used on some patients with GCBT; however, the number of patients with treatment failure in this current 
assessment was small. The statistical evaluation conducted in this meta-analysis showed a clear statistical relevance to the widely varying numbers of patients with GCBT who experienced treatment failure with denosumab in the medical literature publications $[11,12,60-90]$. Despite this efficacy of denosumab, disease progression was unfortunately observed after only a short time among a small proportion of patients in some open-label phase II studies and case reports in this investigation. This result suggests a great need for new treatment strategies and substances to stop the progression of the disease when conventional treatment measures are no longer effective. Notably, denosumab had no response after administration in an admittedly small group of patients with GCBT according to the collected data from the case series of this meta-analysis.

GCBT may well metastasize to the lungs [91]. One study examined the risk factors for lung metastases of GCBT according to the therapeutic measures and a reasonable follow-up time [91]. This earlier study treated patients with GCBT only with surgery and radiotherapy, and lung metastases occurred in $29.3 \%$ of the 141 patients included in the study [91]. The risk factors for lung metastases were identified at a young age and as a local recurrence, and an association was also found between the local recurrence and lung metastases [91]. This earlier study reported the local recurrences and metastases of GCBT within three years after the first surgery; therefore, the authors recommended regular imaging of the original location and the chest in patients with GCBT after the first surgical treatment and for at least three years after surgery [91]. The evaluation of this meta-analysis illustrated nearly the same frequency of lung metastases in GCBT in some open-label phase II studies and case reports, as well as an already existing colonization of the lungs with GCBT in cohort 2 in a case report. Significantly less lung metastasis by GCBT was evident after treatment with denosumab compared with the finding of this earlier study

GCBT occurred predominantly at a young middle age and more commonly among women. The data of the present study agreed with those from large-scale published case series; however, they refuted the data of another study $[11,12,60-90,92]$. Similar to the present study and compared with a Swedish one, the number of patients with osteosarcoma was small [93]. In the Swedish study, the number of patients with osteosarcoma was small compared to previous data from the Swedish Cancer Register [93]. This may be explained by changes in diagnostic evaluation and by the introduction of a multi-disciplinary investigation of GCBT over the years [93].

The latest clinical studies have reported that denosumab treatment has a good tumor response rate in patients with GCBT. However, these studies, which were cited in this research, reported on patients who were still undergoing denosumab treatment or on patients who had undergone denosumab treatment but had only a brief follow-up [11, 12, 60-90]. Other studies described a newly formed bone matrix and thickened cortical bone after treatment with denosumab [92]. In some cases, following denosumab treatment, the surgeon would not allow the true size of the giant cell bone tumor to be differentiated [92], which probably increased the risk of local recurrence. An important point to note is that nine cases of a single transformation of GCBT during treatment with denosumab, without prior radiation treatment, have been reported in the literature [92]. Inhibition of RANKL has been reported to increase the risk of new malignant diseases (e.g., osteosarcoma) because of immunosuppression [65, 94]. 
The most common location of GCBT on the bodies of the patients from all study types in this evaluation was the lower extremities, followed by the upper extremities but with no statistical significance, in agreement with the data of another study [95]. Statistical significance was only observed for the evaluation of tumor localization in the sacrum in cohort $1(P=0.002)$ and in the lower limbs in cohort 2 $(P=0.0024)$ of open-label phase II studies in this investigation. The treatment duration of GCBT with denosumab did not differ in the reviewed studies. As also concluded in an older review, the optimal duration of treatment of GCBT remains unclear [96].

Denosumab was used in this evaluation mainly as a neoadjuvant therapy in patients with GCBT. The use of denosumab as a preoperative or adjuvant treatment in patients with GCBT will still require clinical trials to gain further insights about its efficacy [97].

The occurrence of side effects of denosumab was comparatively low in this study. The most common side effects with statistical significance was osteonecrosis of the jaw in the open-label phase II studies, followed by pain in the limbs in the case series but without statistical relevance (Table 3). However, whether this pain in the limbs represented a drug side effect or a symptom of an underlying GCBT in individual cases can only be determined by a tentative discontinuation of denosumab. In cases of adverse effects of the drug, including any side effects not listed in the accompanying leaflet, denosumab was discontinued in patients with GCBT. The most common symptom of GCBT was pain; however, distinguishing between pain in the limbs due to the tumor and pain possibly caused by denosumab was certainly difficult. Another study indicated that the most common side effects of denosumab, when used to treat patients with cancer, were infection, pain in the limbs, arthralgia, bone pain, and fatigue [98]. The malignancies assessed in that study were bone events from breast and prostate cancer [98]; a serious side effect included infections requiring hospitalization [98]. In the same study, the most common side effects of denosumab in the treatment of patients with osteoporosis were arthralgia, nasopharyngitis, back pain, and headaches [98]. In another study, the most common side effects of denosumab in the treatment of patients with osteoporosis were back pain, pain in the limbs, musculoskeletal pain, and cystitis [99]. Serious but rare side effects reported in that research included the development of severe infections, dermatological changes, and hypocalcemia [99]. The other side effects frequently reported in this meta-analysis regarding the use of denosumab in the treatment of patients with GCBT were fatigue, pathological bone fracture, headache, peripheral neuropathy, and serious adverse events, mainly in the case series but without statistical relevance (Table 3). The side effects seen in the present study, compared with those in the other studies, did not seem to depend on the underlying disease. Denosumab should therefore be considered in patients with GCBT who cannot tolerate other therapies or have adherence problems or contraindications for other therapies. Comparison of the adverse effects of denosumab in the treatment of GCBT indicated that the use of denosumab in patients with metastatic GCBT had severe limitations. Patients with metastatic giant cell bone tumor are generally much more ill when compared with patients with GCBT and receive a much lower dose of denosumab administered much less frequently. 
In conclusion, I would like to compare the present meta-analysis with a systemic review of denosumab in the treatment of GCBT recently published on March 15, 2019, by Luengo-Alonso et al. [100]. The systemic literature search by Luengo-Alonso et al. included a total of 19 studies involving an overall total of 1095 patients [100]. The present work is a meta-analysis of a total of 33 studies with the 350 patients analyzed. The proportion of women was greater than that of men in both studies. The patient ages were not significantly different between the two studies. The recurrence rate of GCBT was $9 \%$ in the other published study, whereas the recurrence rates in the current meta-analysis were as much as $100 \%$. The metastasis rate of GCBT was also as high as $10.5 \%$ in the current study, compared to $3 \%$ in the systemic analysis by Luengo-Alonso et al. The adverse effects of denosumab also differed in the two studies, as the most common adverse events were fatigue and muscle pain in the study by LuengoAlonso et al., while they were osteonecrosis of the jaw, pain in the limbs, and fatigue in the current metaanalysis. The response rate of $95.3 \%$ to $100 \%$ determined in the current meta-analysis for therapy with denosumab indicated that the drug was very effective. By contrast, Luengo-Alonso et al. reported an estimated radiologic response of $66-100 \%$ for their patients.

The use of denosumab as an adjuvant therapy in non-resectable GCBT of bone in both studies revealed positive but distinct histologic changes with consistent radiographic changes, regardless of the various types of adverse drug reactions of this drug. Positive clinical responses of denosumab in the treatment of non-resectable giant cell tumors were pain relief and a decrease in the morbidity of the surgical procedures that were performed. Lastly, the oncological results differed when using denosumab as an adjuvant treatment for non-resectable GCBT and did not affect either lung metastases or local recurrence rates in either study.

\section{Limitations}

The studies examined in this analysis were open-label phase II studies, case series, and case reports. The two approval trials for denosumab for patients with GCBT referred to in this study were also open-label phase II studies [11, 12]. Randomized placebo-controlled trials are lacking for the use of denosumab for the treatment of patients with GCBT. Therefore, a summary of up-to-date results seems useful. Nevertheless, the studies that have been conducted thus far are small and have been performed in different clinical settings. They are also very heterogeneous, and their results have been simplified in this work. Denosumab treatment has been established as a suppressive therapy for GCBT; its effectiveness has also been confirmed here. However, denosumab drug therapy is not curative and is therefore only recommended for inoperable tumors. The duration of therapy with this drug remains unclear; however, it must be assumed to be lifelong, as local recurrences are often described after discontinuation of therapy. In any case, surgery remains the gold standard therapy for GCBT. Denosumab as a preoperative therapy is an interesting new concept that could simplify operations. However, some findings indicate that this procedure increases the postoperative local recurrence rate, as tumor cells survive in the newly formed bone and are thus more difficult to reach during curettage. For this reason, preoperative denosumab is still not accepted as a standard preoperative treatment. 
Studies on pure suppression therapy and on the effectiveness of denosumab in combination with various other therapies, including surgery and embolization, are included in this meta-analysis. For this reason, the response behavior of denosumab was pooled and generalized for comparison with the results of this study design. The clinical setting and the accompanying therapies can have an equally important influence on the outcome and may not have been statistically noted.

The implementation of placebo-controlled studies for denosumab in patients with GCBT would certainly not be allowed for ethical reasons because of the severity of the disease. The open-label phase II studies examined in this study had a high risk of bias because of the insufficient blinding of the outcome assessment and insufficient handling of incomplete outcome data (Fig. 3). By comparison, some case series showed a high risk of bias for the incomplete inclusion of participants and insufficient reporting of the results and statistical analysis (Fig. 4). Only one study had an increased risk of bias for the unclear description of the post-interventional clinical situation of a case report (Fig. 5). Long-term outcomes for denosumab were lacking for patients with GCBT treated with this drug. However, the heterogeneity of studies has been considered in the analyses and interpretation of the results, mainly because the evaluation of study quality as a whole illustrated a low risk of bias across all study types.

\section{Conclusions}

The evidence provided by this meta-analysis did not fully support the use of denosumab as an adjuvant therapy to reduce GBCT size, clinical symptoms, and mortality. This current paper also did not really address the role of GCBT surgery and did not limit the data to cases where complete resection of GCBT with acceptable morbidity was possible. The majority of patients in the study and control groups in the clinical trials were classified as having non-resectable GCBT. The results of this analysis showed significant limitations in view of the low number of patients with GCBT progression and the bias in reporting and publishing case reports. The evidence was insufficient to support the idea that patients with unresectable GCBT could be cured after using denosumab in addition to the surgery performed. However, treatment with denosumab may allow long-term control of the tumor. In addition, the long-term control in the case reports and series was too limited to assess denosumab as a potential remedy. In this metaanalysis, denosumab was determined to be helpful in reducing tumor size and bone complications in patients with advanced GCBT. Following an approval extension of denosumab, several drug-related adverse effects were observed in patients with GCBT who received denosumab as a drug therapy. The use of denosumab showed a good response rate for the treatment of GCBT.

\section{Abbreviations}

CENTRAL: Cochrane central register of controlled trials; Cl: confidence interval; CT: computerized tomography; GBCT: Giant cell bone tumor(s); MRI: magnetic resonance imaging; RANKL: receptor activator of nuclear factor kappa-B ligand; SD: standard deviation

\section{Declarations}


Ethics approval and consent to participate

No ethical approval was required because this work was a literature review.

\section{Consent for publication}

Not applicable.

\section{Availability of data and materials}

\section{Competing interests}

The author declares that he has no competing interests.

\section{Funding}

This review received no funding.

\section{Authors' contributions}

The author conducted and supervised the data collection and the analysis, interpretation, and presentation of the results.

\section{Acknowledgements}

Not Applicable.

\section{Disclosure}

The author has approved the final manuscript.

\section{References}


1. Body JJ, Gatta F, de Cock E, Tao S, Kritikou P, Wimberger P, et al. An observational time and motion study of denosumab subcutaneous injection and zoledronic acid intravenous infusion in patients with metastatic bone disease: results from three European countries. Support Care Cancer. 2017;25:2823-32. doi:10.1007/s00520-017-3697-5.

2. Brodowicz $T$, Hemetsberger $M$, Windhager R. Denosumab for the treatment of giant cell tumor of the bone. Future Oncol. 2015;11:1881-94. doi:10.2217/fon.15.94.

3. Wojcik J, Rosenberg AE, Bredella MA, Choy E, Hornicek FJ, Nielsen GP, et al. Denosumab-treated giant cell tumor of bone exhibits morphologic overlap with malignant giant cell tumor of bone. Am J Surg Pathol. 2016;40:72-80. doi:10.1097/PAS.0000000000000506.

4. Baron R, Ferrari S, Russell RGG. Denosumab and bisphosphonates: different mechanisms of action and effects. Bone. 2011;48:677-92. doi: 10.1016/j.bone.2010.11.020.

5. Roux S, Amazit L, Meduri G, Guiochon-Mantel A, Milgrom E, Mariette X. RANK (receptor activator of nuclear factor kappa B) and RANK ligand are expressed in giant cell tumors of bone. Am J Clin Pathol. 2002;117:210-6. doi:10.1309/BPET-F2PE-P2BD-J3P3.

6. Ottanelli S. Prevention and treatment of bone fragility in cancer patient. Clin Cases Miner Bone Metab. 2015;12:116-29. doi:10.11138/ccmbm/2015.12.2.116.

7. Hu MI, Glezerman IG, Leboulleux S, Insogna K, Gucalp R, Misiorowski W, et al. Denosumab for treatment of hypercalcemia of malignancy. J Clin Endocrinol Metab. 2014;99:3144-52. doi:10.1210/jc.2014-1001.

8. Chen F, Pu F. Safety of denosumab versus zoledronic acid in patients with bone metastases: a metaanalysis of randomized controlled trials. Oncol Res Treat. 2016;39:453-9. doi:10.1159/000447372.

9. Panzica M, Lüke U, Omar M, Länger F, Falck CV, Krettek C. New therapy approaches for giant cell tumors. Unfallchirurg. 2014;117:883-91. doi:10.1007/s00113-014-2580-9 [Article in German].

10. Xie J, Namjoshi M, Wu EQ, Parikh K, Diener M, Yu AP, et al. Economic evaluation of denosumab compared with zoledronic acid in hormone-refractory prostate cancer patients with bone metastases. J Managed Care Pharm. 2011;17:621-34.

11. Thomas D, Henshaw R, Skubitz K, Chawla S, Staddon A, Blay JY, et al. Denosumab in patients with giant-cell tumour of bone: an open-label, phase 2 study. Lancet Oncol. 2010;11:275-80. doi:10.1016/S1470-2045(10)70010-3.

12. Chawla S, Henshaw R, Seeger L, Choy E, Blay JY, Ferrari S, et al. Safety and efficacy of denosumab for adults and skeletally mature adolescents with giant cell tumour of bone: interim analysis of an open-label, parallel-group, phase 2 study. Lancet Oncol. 2013;14:901-8. doi:10.1016/S14702045(13)70277-8.

13. Demirsoy U, Karadogan M, Selek O, Anik Y, Aksu G, Müezzinoglu B, et al. Golden bullet-Denosumab: early rapid response of metastatic giant cell tumor of the bone. J Pediatr Hematol Oncol. 2012;36:156-8. doi: 10.1097/MPH.0000000000000034.

14. Welch V, Petticrew M, Petkovic J, Moher D, Waters E, White H, et al. Extending the PRISMA statement to equity-focused systematic reviews (PRISMA-E 2012): explanation and elaboration. J Dev Effect. 
2016;8:287-324. doi:10.1080/19439342.2015.1113196.

15. Raskin KA, Schwab JH, Mankin HJ, Springfield DS, Hornicek FJ. Giant cell tumor of bone. J Am Acad Orthop Surg. 2013;21:118-26. doi:10.5435/JAAOS-21-02-118.

16. Liu HS, Wang JW. Treatment of giant cell tumor of bone: a comparison of local curettage and wide resection. Changgeng Yi Xue Za Zhi. 1998;21:37-43.

17. Law GW, Yeo NEM, Howe TS, Tan YZ, Tan SB, Siddiqui MMA. Recommencement of denosumab for unresectable giant cell tumor of the cervical spine. Spine. 2018;43:E551-E556. doi:10.1097/BRS.0000000000002440.

18. Chen G, Li J, Li X, Fan H, Guo Z, Wang Z. Giant cell tumor of axial vertebra: surgical experience of five cases and a review of the literature. World J Surg Oncol. 2015;13:62. doi:10.1186/s12957-015-04384.

19. Di Lorenzo N, Delfini R, Ciappetta P, Cantore G, Fortuna A. Primary tumors of the cervical spine: surgical experience with 38 cases. Surg Neurol. 1992;38:12-8. doi:10.1016/0090-3019(92)90206-3.

20. Freeman JL, Oushy S, Schowinsky J, Sillau S, Youssef AS. Invasive giant cell tumor of the lateral skull base: asystematic review, meta-analysis, and case illustration. World Neurosurg. 2016;96:4757. doi: 10.1016/j.wneu.2016.05.086.

21. He SH, Xu W, Sun ZW, Liu WB, Liu YJ, Wei HF, et al. Selective arterial embolization for the treatment of sacral and pelvic giant cell tumor: a systematic review. Orthop Surg. 2017;9:139-44. doi:10.1111/os.12336.

22. Righi $S$, Boffano P, Patetta R, Malvè L, Pateras $D$, De Matteis $P$, et al. Soft tissue giant cell tumor of low malignant potential with 3 localizations: report of a case. Oral Surg Oral Med Oral Pathol Oral Radiol. 2014;118:e135-e138. doi: 10.1016/j.0000.2014.03.013.

23. Tubbs WS, Brown LR, Beabout JW, Rock MG, Unni KK. Benign giant-cell tumor of bone with pulmonary metastases: clinical findings and radiologic appearance of metastases in 13 cases. Am J Roentgenol. 1992;158:331-4. doi:10.2214/ajr.158.2.1729794

24. Cao H, Lin F, Hu Y, Zhao L, Yu X, Wang Z, et al. Epidemiological and clinical features of primary giant cell tumors of the distal radium: a multicenter retrospective study in China. Sci Rep. 2017;7:9067. doi:10.1038/s41598-017-09486-6.

25. Akahane T, Isobe K, Shimizu T. Serum total acid phosphatase for monitoring the clinical course of giant cell tumors of bone-26 patients with 5 local recurrences. Acta Orthop. 2005;76:651-3. doi:10.1080/17453670510041727.

26. Ghouchani A, Rouhi G. The great need of a biomechanical-based approach for surgical methods of giant cell tumor: a critical review. J Med Biol Eng. 2017;37:454-67. doi:10.1007/s40846-017-0278-5.

27. He Y, Wang J, Zhang J, Yuan F, Ding X. A prospective study on predicting local recurrence of giant cell tumour of bone by evaluating preoperative imaging features of the tumour around the knee joint. Radiol Med. 2017;122:546-55. doi:10.1007/s11547-017-0745-7.

28. Broehm CJ, Inwards CY, Al-lbraheemi A, Wenger DE, Jenkins SM, Jin L, et al. Giant cell tumor of bone in patients 55 years and older. Am J Clin Pathol. 2018;149:222-33. doi:10.1093/ajcp/aqx155. 
29. Bonar J, Carr SC, De Carvalho D, Wunder JS. Differentiating giant cell tumor of bone from patellofemoral syndrome: a case study. J Can Chiropr Assoc. 2016;60:57-65.

30. Panchwagh Y, Joshi S, Sancheti P. Benign aggressive lesions of femoral head and neck: Is salvage possible? Indian J Orthop. 2018;52:51-7. doi: 10.4103/ortho.IJOrtho_209_17.

31. McCarthy CL, Gibbons CLMH, Bradley KM, Hassan AB, Giele H, Athanasou NA. Giant cell tumour of the distal radius/ulna: response to pre-operative treatment with short-term denosumab. Clin Sarcoma Res. 2017;7:19. doi: 10.1186/s13569-017-0085-3.

32. Yamagishi T, Kawashima H, Ogose A, Ariizumi T, Sasaki T, Hatano H, et al. Receptor-activator of nuclear kappaB ligand expression as a new therapeutic target in primary bone tumors. PLoS One. 2016;11:e0154680. doi: 10.1371/journal.pone.0154680.

33. Lewin J, Thomas D. Denosumab: a new treatment option for giant cell tumor of bone. Drugs Today (Barc). 2013;49:693-700. doi:10.1358/dot.2013.49.11.2064725.

34. Martin-Broto J, Cleeland CS, Glare PA, Engellau J, Skubitz KM, Blum RH, et al. Effects of denosumab on pain and analgesic use in giant cell tumor of bone: interim results from a phase II study. Acta Oncol. 2014;53:1173-9. doi:10.3109/0284186X.2014.910313.

35. Verma V, Puri A, Shah S, Rekhi B, Gulia A. Giant cell tumor developing in Paget's disease of bone: a case report with review of literature. J Orthop Case Rep. 2016;6:103-7. doi: 10.13107/jocr.22500685.594 .

36. Kim SY, Ok HG, Birkenmaier C, Kim KH. Can denosumab be a substitute, competitor, or compliment to bisphosphonates? Korean J Pain. 2017;30:86-92. doi:10.3344/kjp.2017.30.2.86.

37. Eisenhauer EA, Therasse P, Bogaerts J, Schwartz LH, Sargent D, Ford R, et al. New response evaluation criteria in solid tumours: revised RECIST guideline (version 1.1). Eur $J$ Cancer. 2009;45:228-47. doi: 10.1016/j.ejca.2008.10.026.

38. D'Amico A. Review of clinical practice utility of positron emission tomography with 18Ffluorodeoxyglucose in assessing tumour response to therapy. Radiol Med. 2015;120:345-51. doi:10.1007/s11547-014-0446-4.

39. Stopeck AT, Fizazi K, Body JJ, Brown JE, Carducci M, Diel I, et al. Safety of long-term denosumab therapy: results from the open-label extension phase of two phase 3 studies in patients with metastatic breast and prostate cancer. Support Care Cancer. 2016;24:447-55. doi:10.1007/s00520015-2904-5.

40. Fizazi K, Bosserman L, Gao G, Skacel T, Markus R. Denosumab treatment of prostate cancer with bone metastases and increased urine n-telopeptide levels after therapy with intravenous bisphosphonates: results of a randomized phase ii trial. J Urol. 2009;182: 509-16. doi: 10.1016/j.juro.2009.04.023.

41. Syversen U, Halse JI, Geisler J, Eriksen EF. Denosumab for treatment of postmenopausal osteoporose. Tidsskr Nor Laegeforen. 2011;131:1893-6. doi:10.4045/tidsskr.10.1116 [Article in Norwegian]. 
42. Fizazi K, Carducci M, Smith M, Damião R, Brown J, Karsh L, et al. Denosumab versus zoledronic acid for treatment of bone metastases in men with castration-resistant prostate cancer: a randomised, double-blind study. Lancet. 2011;377:813-22. doi:10.1016/S0140-6736(10)62344-6.

43. National Cancer Institute, Division of Cancer Treatment \& Diagnosis, Common Terminology Criteria for Adverse Events (CTCAE). 2018.

https://ctep.cancer.gov/protocoldevelopment/electronic_applications/ctc.htm. Accessed 28 Feb 2018.

44. Li D, Ma H, Zhang W, Sun C, Lu X, Gao Y, et al. [Analysis of implant-related complications after hinge knee replacement for tumors around the knee]. Zhongguo Xiu Fu Chong Jian Wai Ke Za Zhi. 2015;29:936-40. [Article in Chinese].

45. Zheng K, Yu XC, Hu YC, Wang Z, Wu SJ, Ye ZM. How to fill the cavity after curettage of giant cell tumors around the knee? A multicenter analysis. Chin Med J. 2017;130:2541-6. doi:10.4103/03666999.217093.

46. Luchetti TJ, Wysocki RW, Cohen MS. Distal radius allograft reconstruction utilizing a step-cut technique after en bloc tumor resection. Hand (NY). 2018;1:1558944717751193. doi:10.1177/1558944717751193.

47. Zhang S, Xu MT, Wang XQ, Wang JJ. Functional outcome of en bloc excision and custom prosthetic replacement for giant cell tumor of the distal radius. J Ortop Sci. 2015;20:1090-7. doi:10.1007/s00776-015-0763-z.

48. Xu L, Jin J, Hu A, Xiong J, Wang D, Sun Q, et al. Soft tissue recurrence of giant cell tumor of the bone: prevalence and radiographic features. J Bone Oncol. 2017;9:10-14. doi: 10.1016/j.jbo.2017.09.002.

49. Yin $\mathrm{H}$, Cheng, M, Li B, Li B, Wang P, Meng T, et al. Treatment and outcome of malignant giant cell tumor in the spine. J Neuro-Oncol. 2015;124:275-81. doi:10.1007/s11060-015-1835-9.

50. Kim SY, Park JE, Lee YJ, Seo HJ, Sheen SS, Hahn S, et al. Testing a tool for assessing the risk of bias for nonrandomized studies showed moderate reliability and promising validity. J Clin Epidemiol. 2013;66:408-14.

51. Joanna Briggs Institute, Critical appraisal tools for use in systematic reviews, Checklist for case series. 2018. http://joannabriggs.org/research/critical-appraisal-tools.html. Accessed 28 Feb. 2018.

52. Moola S, Munn Z, Sears K, Sfetcu R, Currie M, Lisy K, et al. Conducting systematic reviews of association (etiology): the Joanna Briggs Institute's approach. Int J Evid Based Healthc. 2015;13:163-9.

53. Joanna Briggs Institute, Critical appraisal tools for use in systematic reviews, checklist for case reports. 2018. http://joannabriggs.org/research/critical-appraisal-tools.html. Accessed 28 Feb. 2018.

54. Gagnier JJ, Kienle G, Altman DG, Moher D, Sox H, Riley D. CARE Group. The CARE guidelines: consensus-based clinical case report guideline development. J Diet Suppl. 2013;10:381-90.

55. Martin M, Bell R, Bourgeois H, Brufsky A, Diel I, Eniu A, et al. Bone-related complications and quality of life in advanced breast cancer: results from a randomized phase III trial of denosumab versus zoledronic acid. Clin Cancer Res. 2012;18:4841-9. doi: 10.1158/1078-0432.CCR-11-3310. 
56. Kummer J, Internetservice Kummer und Oster, Mühlenstr. 6, 87474 Buchenberg, Germany. Statistik Rechner-Jumk.de. Calculator for producing statistics about a dataset. Averages and other statistical measures. 2018. https://jumk.de/statistik-rechner/. Accessed 28 Feb. 2018.

57. Navendu Vasavada Statistics. Mann Whitney test for unpaired data, two sample. 2016. http://astatsa.com/WilcoxonTest/. Accessed 28 Feb. 2018.

58. Lowry R. Contingency table-VassarStats. 2018. http://vassarstats.net/newcs.html. Accessed 28 Feb. 2018.

59. Allto Consulting, Interval calculator for proportions. 2018. https://www.allto.co.uk/tools/statisticcalculators/confidence-interval-for-proportions-calculator/. Accessed 28 Feb. 2018.

60. Ji T, Yang Y, Wang Y, Sun K, Guo W. Combining of serial embolization and denosumab for large sacropelvic giant cell tumor: case report of 3 cases. Medicine. 2017;96:e7799. doi:10.1097/MD.0000000000007799.

61. Satcher RL, Ravi V, Wang WL, Oates S. Postpartum treatment of metastatic recurrent giant cell tumor of capitate bone of wrist. Am J Orthop. 2017;46:E269-E275.

62. Palmerini E, Chawla NS, Ferrari S, Sudan M, Picci P, Marchesi E, et al. Denosumab in advanced/unresectable giant-cell tumour of bone (GCTB): for how long? Eur J Cancer. 2017;76:11824. doi: 10.1016/j.ejca.2017.01.028.

63. Yonezawa N, Murakami H, Kato S, Takeuchi A, Tsuchiya H. Giant cell tumor of the thoracic spine completely removed by total spondylectomy after neoadjuvant denosumab therapy. Eur Spine J. 2017;26(Suppl. 1):236-42. doi:10.1007/s00586-017-5086-7.

64. von Borstel D, Taguibao RA, Strle NA, Burns JE. Giant cell tumor of the bone: aggressive case initially treated with denosumab and intralesional surgery. Skelet Radiol. 2017;46:571-8. doi:10.1007/s00256-017-2588-7.

65. Bardakhchyan S, Kager L, Danielyan S, Avagyan A, Karamyan N, Vardevanyan H, et al. Denosumab treatment for progressive skull base giant cell tumor of bone in a 14-year-old female-a case report and literature review. Ital J Pediatr. 2017;43:32. doi:10.1186/s13052-017-0353-0.

66. Tsukamoto S, Righi A, Vanel D, Honoki K, Donati DM, Errani C. Development of high-grade osteosarcoma in a patient with recurrent giant cell tumor of the ischium while receiving treatment with denosumab. Jpn J Clin Oncol. 2017;47:1090-6. doi:10.1093/jjco/hyx112.

67. Deveci MA, Paydaş S, Gönlüşen G, Özkan C, Biçer ÖS, Tekin M. Clinical and pathological results of denosumab treatment for giant cell tumors of bone: prospective study of 14 cases. Acta Orthop Traumatol Turc. 2017;51:1-6. doi: 10.1016/j.aott.2016.03.004.

68. Rekhi B, Verma V, Gulia A, Jambhekar NA, Desai S, Juvekar SL, et al. Clinicopathological features of a series of 27 cases of post-denosumab treated giant cell tumors of bones: a single institutional experience at a tertiary cancer referral centre, India. Pathol Oncol Res. 2017;23:157-64. doi:10.1007/s12253-016-0123-0.

69. Menon PD, Krishnakumar R. Radiological and histopathological outcome of giant cell tumor of femur with denosumab treatment: a case report. J Clin Diagn Res. 2016;10: RD01-RD03. 
doi:10.7860/JCDR/2016/22172.9070.

70. Müller DA, Beltrami G, Scoccianti G, Campanacci DA, Franchi A, Capanna R. Risks and benefits of combining denosumab and surgery in giant cell tumor of bone-a case series. World J Surg Oncol. 2016;14:281.

71. Inoue A, Ohnishi T, Kohno S, Nishikawa M, Nishida N, Ohue S. Role of denosumab in endoscopic endonasal treatment for juvenile clival giant cell tumor: a case report and review of the literature. World Neurosurg. 2016;91:674.e1-674.e6. doi: 10.1016/j.wneu.2016.04.054.

72. Traub F, Singh J, Dickson BC, Leung S, Mohankumar R, Blackstein ME, et al. Efficacy of denosumab in joint preservation for patients with giant cell tumour of the bone. Eur $\mathrm{J}$ Cancer. 2016;59:1-12. doi: 10.1016/j.ejca.2016.01.006.

73. de Carvalho Cavalcante RA, Silva Marques RA, Santos VGD, Sabino E, Fraga AC, Zaccariotti VA, et al. Spondylectomy for giant cell tumor after denosumab therapy. Spine. 2016;41:E178-E182. doi:10.1097/BRS.0000000000001191.

74. Yamagishi T, Kawashima H, Ogose A, Sasaki T, Hotta T, Inagawa S, et al. Disappearance of giant cells and presence of newly formed bone in the pulmonary metastasis of a sacral giant-cell tumor following denosumab treatment: a case report. Oncol Lett. 2016;11:243-6. doi:10.3892/ol.2015.3858.

75. Kajiwara D, Kamoda H, Yonemoto $\mathrm{T}$, Iwata $\mathrm{S}$, Ishii $\mathrm{T}$, Tsukanishi $\mathrm{T}$, et al. Denosumab for treatment of a recurrent cervical giant-cell tumor. Asian Spine J. 2016;10:553-7. doi:10.4184/asj.2016.10.3.553.

76. Nakazawa T, Inoue G, Imura T, Miyagi M, Saito W, Namba T, et al. Remarkable regression of a giant cell tumor of the cervical spine treated conservatively with denosumab: a case report. Int J Surg Case Rep. 2016;24:22-5. doi: 10.1016/j.ijscr.2016.05.008.

77. Setsu N, Kobayashi E, Asano N, Yasui N, Kawamoto H, Kawai A, et al. Severe hypercalcemia following denosumab treatment in a juvenile patient. J Bone Miner Metab. 2016;34:118-22. doi:10.1007/s00774-015-0677-z.

78. Aponte-Tinao LA, Piuzzi NS, Roitman P, Farfalli GL. A high-grade sarcoma arising in a patient with recurrent benign giant cell tumor of the proximal tibia while receiving treatment with denosumab. Clin Orthop Relat Res. 2015;473:3050-5. doi:10.1007/s11999-015-4249-2.

79. Park MJ, Ganjoo KN, Ladd AL. Denosumab, a potential alternative to the surgical treatment of distal radius giant cell tumor of bone: case report. J Hand Surg (USA). 2015;40:1620-4. doi:

10.1016/j.jhsa.2015.03.018.

80. Matcuk GR, Patel DB, Schein AJ, White EA, Menendez LR. Giant cell tumor: rapid recurrence after cessation of long-term denosumab therapy. Skelet Radiol. 2015;44:1027-31. doi:10.1007/s00256015-2117-5.

81. Vaishya R, Agarwal AK, Vijay V, Vaish A. Metachronous multicentric giant cell tumour in a young woman. BMJ Case Rep. 2015;5. doi:10.1136/bcr-2015-209368.

82. Goldschlager T, Dea N, Boyd M, Reynolds J, Patel S, Rhines LD, et al. Giant cell tumors of the spine: has denosumab changed the treatment paradigm? J Neurosurg Spine. 2015;22:526-33. 
doi:10.3171/2014.10.SPINE13937.

83. Gossai N, Hilgers MV, Polgreen LE, Greengard EG. Critical hypercalcemia following discontinuation of denosumab therapy for metastatic giant cell tumor of bone. Pediatr Blood Cancer. 2015;62:1078-80. doi:10.1002/pbc.25393.

84. Watanabe N, Matsumoto S, Shimoji T, Ae K, Tanizawa T, Gokita T, et al. Early evaluation of the therapeutic effect of denosumab on tartrate-resistant acid phosphatase $5 \mathrm{~b}$ expression in a giant cell tumor of bone: a case report. BMC Res Notes. 2014;7:608. doi:10.1186/1756-0500-7-608.

85. Mattei TA, Ramos E, Rehman AA, Shaw A, Patel SR, Mendel E. Sustained long-term complete regression of a giant cell tumor of the spine after treatment with denosumab. Spine J. 2014;14:e15e21. doi: 10.1016/j.spinee.2014.02.019.

86. Hakozaki M, Tajino T, Yamada H, Hasegawa O, Tasaki K, Watanabe K, et al. Radiological and pathological characteristics of giant cell tumor of bone treated with denosumab. Diagn Pathol. 2014;9:111. doi:10.1186/1746-1596-9-111.

87. Aghaloo TL, Dry SM, Mallya S, Tetradis S. Stage 0 osteonecrosis of the jaw in a patient on denosumab. J Oral Maxillofac Surg. 2014;72:702-16. doi: 10.1016/j.joms.2013.09.008.

88. Rossi B, Ferraresi V, Appetecchia ML, Novello M, Zoccali C. Giant cell tumor of bone in a patient with diagnosis of primary hyperparathyroidism: a challenge in differential diagnosis with brown tumor. Skelet Radiol. 2014;43:693-7. doi:10.1007/s00256-013-1770-9.

89. Akaike K, Suehara Y, Takagi T, Kaneko K, Saito T. An eggshell-like mineralized recurrent lesion in the popliteal region after treatment of giant cell tumor of the bone with denosumab. Skelet Radiol. 2014;43:1767-72. doi:10.1007/s00256-014-1961-z.

90. Branstetter DG, Nelson SD, Manivel JC, Blay JY, Chawla S, Thomas DM, et al. Denosumab induces tumor reduction and bone formation in patients with giant-cell tumor of bone. Clin Cancer Res. 2012;18:4415-24. doi: 10.1158/1078-0432.CCR-12-0578.

91. Kito M, Matusmoto S, Ae K, Tanizawa T, Gokita T, Kobayashi H, et al. Pulmonary metastasis from giant cell tumor of bone: clinical outcome prior to the introduction of molecular target therapy. Jpn J Clin Oncol. 2017;47:529-34. doi: 10.1093/jjco/hyx033.

92. Errani C, Tsukamoto S, Mavrogenis AF. How safe and effective is denosumab for bone giant cell tumour? Int Orthop. 2017;41:2397-400. doi: 10.1007/s00264-017-3536-9.

93. Rockberg J, Bach BA, Amelio J, Hernandez RK, Sobocki P, Engellau J, et al. Incidence trends in the diagnosis of giant cell tumor of bone in Sweden since 1958. J Bone Jt Surg Am. 2014;97:1756-66. doi:10.2106/JBJS.0.00156.

94. Errani C, Tsukamoto S, Leone G, Righi A, Akahane M, Tanaka Y, et al. Denosumab may increase the risk of local recurrence in patients with giant-cell tumor of bone treated with curettage. $J$ Bone Joint Surg Am. 2018;100:496-504. doi: 10.2106/JBJS.17.00057.

95. Muramatsu K, Ihara K, Taguchi T. Treatment of giant cell tumor of long bones: clinical outcome and reconstructive strategy for lower and upper limbs. Orthopedics. 2009;32:491. doi:10.3928/0147744720090527-08. 
96. van der Heijden L, Dijkstra PDS, Blay JY, Gelderblom H. Giant cell tumour of bone in the denosumab era. Eur J Cancer. 2017;77:75-83. doi: 10.1016/j.ejca.2017.02.021.

97. Skubitz KM. Giant cell tumor of bone: current treatment options. Curr Treat Options Oncol. 2014;15:507-18. doi:10.1007/s11864-014-0289-1.

98. Burkiewicz JS, Scarpace SL, Bruce SP. Denosumab in osteoporosis and oncology. Ann Pharmacother. 2009;43:1445-55. doi:10.1345/aph.1M102.

99. Kyrgidis A, Toulis K. Safety and efficacy of denosumab in giant-cell tumour of bone. Lancet Oncol. 2010;11:513-4. doi: 10.1016/S1470-2045(10)70059-0.

100. Luengo-Alonso G, Mellado-Romero M, Shemesh S, Ramos-Pascua L, Pretell-Mazzini J. Denosumab treatment for giant-cell tumor of bone: a systematic review of the literature. Arch Orthop Trauma Surg. 2019 Mar 15. doi: 10.1007/s00402-019-03167-x.

\section{Tables}

Table 1 List of references used for this systematic review 


\begin{tabular}{|c|c|c|c|c|c|}
\hline $\begin{array}{l}\text { Study } \\
\text { number }\end{array}$ & Citation & $\begin{array}{l}\text { Study } \\
\text { type }\end{array}$ & $\begin{array}{l}\text { Country of } \\
\text { the main } \\
\text { author }\end{array}$ & $\begin{array}{l}\text { Total } \\
\text { number } \\
\text { of study } \\
\text { patients }\end{array}$ & $\begin{array}{l}\text { Number of } \\
\text { patients } \\
\text { considered } \\
\text { for this } \\
\text { study }\end{array}$ \\
\hline & $\begin{array}{l}\text { Ji T, Yang Y, Wang Y, Sun K, Guo W. Combining of } \\
\text { serial embolization and denosumab for large } \\
\text { sacropelvic giant cell tumor: case report of } 3 \text { cases. } \\
\text { Medicine. 2017;96:e7799. }\end{array}$ & $\begin{array}{l}\text { Case } \\
\text { series }\end{array}$ & China & 3 & 3 \\
\hline & $\begin{array}{l}\text { Satcher RL, Ravi V, Wang WL, Oates S. Postpartum } \\
\text { treatment of metastatic recurrent giant cell tumor of } \\
\text { capitate bone of wrist. Am J Orthop. 2017;46:E269- } \\
\text { E275. }\end{array}$ & $\begin{array}{l}\text { Case } \\
\text { report }\end{array}$ & $\begin{array}{l}\text { United } \\
\text { States }\end{array}$ & 1 & 1 \\
\hline & $\begin{array}{l}\text { Palmerini E, Chawla NS, Ferrari S, Sudan M, Picci P, } \\
\text { Marchesi E, et al. Denosumab in } \\
\text { advanced/unresectable giant-cell tumour of bone } \\
\text { (GCTB): for how long? Eur J Cancer. 2017;76:118-24. }\end{array}$ & $\begin{array}{l}\text { Open } \\
\text { label }\end{array}$ & Italy & 97 & 54 \\
\hline & $\begin{array}{l}\text { Yonezawa N, Murakami H, Kato S, Takeuchi A, } \\
\text { Tsuchiya H. Giant cell tumor of the thoracic spine } \\
\text { completely removed by total spondylectomy after } \\
\text { neoadjuvant denosumab therapy. Eur Spine J. 2017;26 } \\
\text { (Suppl. 1):236-42. }\end{array}$ & $\begin{array}{l}\text { Case } \\
\text { report }\end{array}$ & Japan & 1 & 1 \\
\hline & $\begin{array}{l}\text { von Borstel D, Taguibao RA, Strle NA, Burns JE. Giant } \\
\text { cell tumor of the bone: aggressive case initially } \\
\text { treated with denosumab and intralesional surgery. } \\
\text { Skelet Radiol. 2017;46:571-8. }\end{array}$ & $\begin{array}{l}\text { Case } \\
\text { report }\end{array}$ & $\begin{array}{l}\text { United } \\
\text { States }\end{array}$ & 1 & 1 \\
\hline & $\begin{array}{l}\text { Bardakhchyan S, Kager L, Danielyan S, Avagyan A, } \\
\text { Karamyan N, Vardevanyan H, et al. Denosumab } \\
\text { treatment for progressive skull base giant cell tumor } \\
\text { of bone in a } 14 \text { year old female-a case report and } \\
\text { literature review. Ital J Pediatr. 2017;43:32. }\end{array}$ & $\begin{array}{l}\text { Case } \\
\text { report }\end{array}$ & Armenia & 1 & 1 \\
\hline & $\begin{array}{l}\text { Tsukamoto S, Righi A, Vanel D, Honoki K, Donati DM, } \\
\text { Errani C. Development of high-grade osteosarcoma in } \\
\text { a patient with recurrent giant cell tumor of the } \\
\text { ischium while receiving treatment with denosumab. } \\
\text { Jpn J Clin Oncol. 2017;47:1090-6. }\end{array}$ & $\begin{array}{l}\text { Case } \\
\text { report }\end{array}$ & Japan & 1 & 1 \\
\hline & $\begin{array}{l}\text { Deveci MA, Paydaş S, Gönlüşen G, Özkan C, Biçer ÖS, } \\
\text { Tekin M. Clinical and pathological results of } \\
\text { denosumab treatment for giant cell tumors of bone: } \\
\text { prospective study of } 14 \text { cases. Acta Orthop Traumatol } \\
\text { Turc. 2017;51:1-6. }\end{array}$ & $\begin{array}{l}\text { Case } \\
\text { series }\end{array}$ & Turkey & 14 & 13 \\
\hline & $\begin{array}{l}\text { Rekhi B, Verma V, Gulia A, Jambhekar NA, Desai S, } \\
\text { Juvekar SL, et al. Clinicopathological features of a } \\
\text { series of } 27 \text { cases of post-denosumab treated giant } \\
\text { cell tumors of bones: a single institutional experience } \\
\text { at a tertiary cancer referral centre, India. Pathol } \\
\text { Oncol Res. 2017;23:157-64. }\end{array}$ & $\begin{array}{l}\text { Case } \\
\text { series }\end{array}$ & India & 27 & 27 \\
\hline- & $\begin{array}{l}\text { Menon PD, Krishnakumar R. Radiological and } \\
\text { histopathological outcome of giant cell tumor of femur } \\
\text { with denosumab treatment: a case report. J Clin Diagn } \\
\text { Res. 2016;10:RD01-RD03. }\end{array}$ & $\begin{array}{l}\text { Case } \\
\text { report }\end{array}$ & India & 1 & 1 \\
\hline & $\begin{array}{l}\text { Müller DA, Beltrami G, Scoccianti G, Campanacci DA, } \\
\text { Franchi A, Capanna R. Risks and benefits of } \\
\text { combining denosumab and surgery in giant cell tumor } \\
\text { of bone-a case series. World J Surg Oncol. } \\
\text { 2016;14:281. }\end{array}$ & $\begin{array}{l}\text { Case } \\
\text { series }\end{array}$ & Switzerland & 25 & 25 \\
\hline & Inoue A, Ohnishi T, Kohno S, Nishikawa M, Nishida N, & Case & Japa & 1 & 1 \\
\hline
\end{tabular}


Ohue S. Role of denosumab in endoscopic endonasal

treatment for juvenile clival giant cell tumor: a case

report and review of the literature. World Neurosurg.

2016;91:674.e1-674.e6.

Traub F, Singh J, Dickson BC, Leung S, Mohankumar

$\mathrm{R}$, Blackstein ME, et al. Efficacy of denosumab in joint

preservation for patients with giant cell tumour of the

bone. Eur J Cancer. 2016;59:1-12.

de Carvalho Cavalcante RA, Silva Marques RA,

Santos VGD, Sabino E, Fraga AC, Zaccariotti VA, et al.

Spondylectomy for giant cell tumor after denosumab

therapy. Spine. 2016;41:E178-E182.

Yamagishi T, Kawashima H, Ogose A, Sasaki T, Hotta

$\mathrm{T}$, Inagawa $\mathrm{S}$, et al. Disappearance of giant cells and

presence of newly formed bone in the pulmonary

metastasis of a sacral giant-cell tumor following

denosumab treatment: a case report. Oncol Lett.

2016;11:243-6.

Kajiwara D, Kamoda H, Yonemoto T, Iwata S, Ishii T,

Tsukanishi $\mathrm{T}$, et al. Denosumab for treatment of a

recurrent cervical giant-cell tumor. Asian Spine J.

2016;10:553-7.

Nakazawa T, Inoue G, Imura T, Miyagi M, Saito W,

Namba T, et al. Remarkable regression of a giant cell

tumor of the cervical spine treated conservatively

with denosumab: a case report. Int J Surg Case Rep.

2016;24:22-5.

Setsu N, Kobayashi E, Asano N, Yasui N, Kawamoto

$\mathrm{H}$, Kawai A, et al. Severe hypercalcemia following

denosumab treatment in a juvenile patient. J Bone

Miner Metab. 2016;34:118-22.

Aponte-Tinao LA, Piuzzi NS, Roitman P, Farfalli GL. A

high-grade sarcoma arising in a patient with recurrent

benign giant cell tumor of the proximal tibia while

receiving treatment with denosumab. Clin Orthop

Relat Res. 2015;473:3050-5.

Park MJ, Ganjoo KN, Ladd AL. Denosumab, a

potential alternative to the surgical treatment of

distal radius giant cell tumor of bone: case report. J

Hand Surg (USA). 2015;40:1620-4.

Matcuk GR, Patel DB, Schein AJ, White EA, Menendez

LR. Giant cell tumor: rapid recurrence after cessation

of long-term denosumab therapy. Skelet Radiol.

2015;44:1027-31.

Vaishya R, Agarwal AK, Vijay V, Vaish A.

Metachronous multicentric giant cell tumour in a

young woman. BMJ Case Rep. 2015;5.

Goldschlager T, Dea N, Boyd M, Reynolds J, Patel S,

Rhines LD, et al. Giant cell tumors of the spine: has

denosumab changed the treatment paradigm? J

Neurosurg Spine. 2015;22:526-33.

Gossai N, Hilgers MV, Polgreen LE, Greengard EG.

Critical hypercalcemia following discontinuation of

denosumab therapy for metastatic giant cell tumor of

bone. Pediatr Blood Cancer. 2015;62:1078-80.

Watanabe N, Matsumoto S, Shimoji T, Ae K, Tanizawa

$\mathrm{T}$, Gokita T, et al. Early evaluation of the therapeutic

effect of denosumab on tartrate-resistant acid

report

$\begin{array}{llll}\begin{array}{l}\text { Case } \\ \text { series }\end{array} & \text { Canada } & 20 & 20\end{array}$

$\begin{array}{llll}\text { Case } & \text { Brazil } & 1 & 1\end{array}$

report

Case

Japan

1

report

Bra

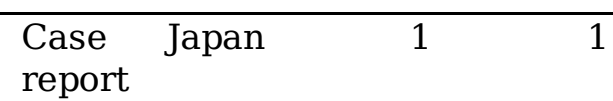

Case Japan $\quad 1 \quad 1$

report

Case

Japan

1

report

Case

Argentina

1

report

.


phosphatase $5 \mathrm{~b}$ expression in a giant cell tumor of bone: a case report. BMC Res Notes. 2014;7:608.

Mattei TA, Ramos E, Rehman AA, Shaw A, Patel SR,

Mendel E. Sustained long-term complete regression

Case United

1

1

of a giant cell tumor of the spine after treatment with

report States

denosumab. Spine J. 2014;14:e15-e21.

Hakozaki M, Tajino T, Yamada $\mathrm{H}$, Hasegawa O,

Tasaki K, Watanabe K, et al. Radiological and

pathological characteristics of giant cell tumor of

bone treated with denosumab. Diagn Pathol.

2014;9:111.

Aghaloo TL, Dry SM, Mallya S, Tetradis S. Stage $0 \quad$ Case $\quad$ United

Case Japan 11

report

osteonecrosis of the jaw in a patient on denosumab. J

Oral Maxillofac Surg. 2014;72:702-16.

Rossi B, Ferraresi V, Appetecchia ML, Novello M,

Zoccali C. Giant cell tumor of bone in a patient with

report States

diagnosis of primary hyperparathyroidism: a

challenge in differential diagnosis with brown tumor.

Skelet Radiol. 2014;43:693-97.

Akaike K, Suehara Y, Takagi T, Kaneko K, Saito T. An

eggshell-like mineralized recurrent lesion in the

popliteal region after treatment of giant cell tumor of

Case Italy

report

the bone with denosumab. Skelet Radiol.

2014;43:1767-72.

Chawla S, Henshaw R, Seeger L, Choy E, Blay JY,

Ferrari S, et al. Safety and efficacy of denosumab for

adults and skeletally mature adolescents with giant

cell tumour of bone: interim analysis of an open-label,

parallel-group, phase 2 study. Lancet Oncol. study

2013;14:901-8.

Branstetter DG, Nelson SD, Manivel JC, Blay JY,

Chawla S, Thomas DM, et al. Denosumab induces

tumor reduction and bone formation in patients with

giant-cell tumor of bone. Clin Cancer Res.

2012;18:4415-24.

Open
label,
phase
II
study

Case
report

Japan

1

1

Thomas D, Henshaw R, Skubitz K, Chawla S, Staddon

A, Blay JY, et al. Denosumab in patients with giant-cell tumour of bone: an open-label, phase 2 study. Lancet Oncol. 2010;11:275-80. doi:10.1016/S14702045(10) 70010-3.

$\begin{array}{llll}\begin{array}{l}\text { Open } \\ \text { label, } \\ \text { phase }\end{array} & \text { United } & 37 & 20 \\ \text { II } & & & \\ \text { study } & & & \\ \begin{array}{l}\text { Open } \\ \text { label, }\end{array} & \text { United } & 35 & 35 \\ \text { phase } & & & \\ \begin{array}{l}\text { II } \\ \text { study }\end{array} & & & \\ \end{array}$

Table 2 Comparison of basic demographic data, characteristics of giant cell bone tumors, treatment procedures with denosumab, and outcome of the therapy in patients with giant cell bone tumors across the non-randomized, uncontrolled, open-label phase II studies, case series, and case reports 


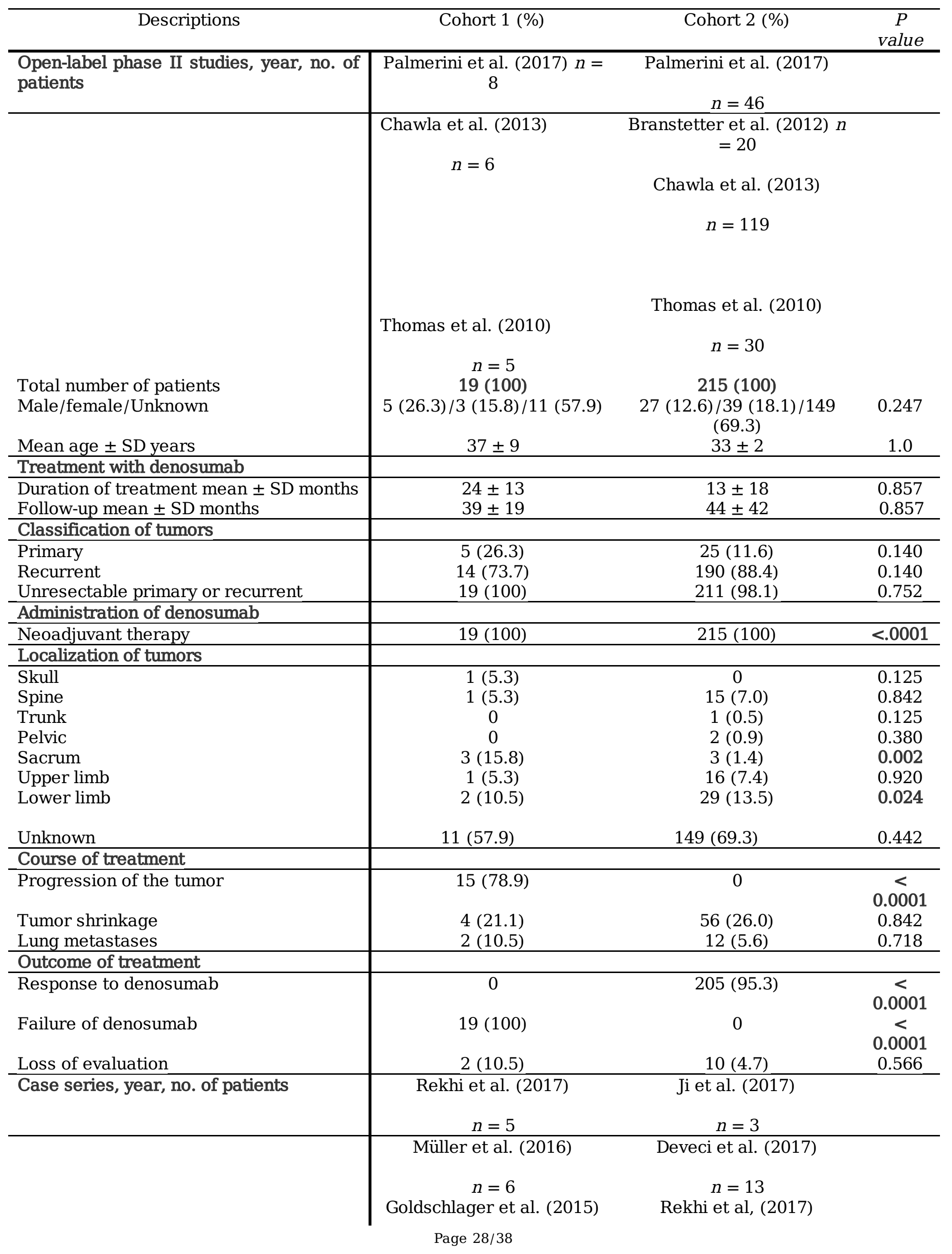




\begin{tabular}{|c|c|c|c|}
\hline & $n=1$ & $\begin{array}{l}\quad n=22 \\
\text { Müller et al. (2016) } \\
\quad n=19\end{array}$ & \\
\hline $\begin{array}{l}\text { Total number of patients } \\
\text { Male/female }\end{array}$ & $\begin{array}{c}12(100) \\
3(25.0) / 9(75.0)\end{array}$ & $\begin{array}{c}\text { Traub et al. (2016) } \\
n=20 \\
\text { Goldschlager et al. (2015) } \\
n=4 \\
81(100) \\
42(51.9) / 39(48.1)\end{array}$ & 0.153 \\
\hline Mean age \pm SD years & $28 \pm 4$ & $35 \pm 4$ & 0.150 \\
\hline \multicolumn{4}{|l|}{ Treatment with denosumab } \\
\hline $\begin{array}{l}\text { Duration of treatment mean } \pm \text { SD months } \\
\text { Follow-up mean } \pm \text { SD months }\end{array}$ & $\begin{array}{c}9 \pm 3 \\
16 \pm 8 \\
\end{array}$ & $\begin{array}{c}15 \pm 8 \\
39 \pm 37 \\
\end{array}$ & $\begin{array}{l}0.262 \\
0.262 \\
\end{array}$ \\
\hline \multicolumn{4}{|l|}{ Classification of tumors } \\
\hline $\begin{array}{l}\text { Primary } \\
\text { Recurrent } \\
\text { Unresectable primary or recurrent }\end{array}$ & $\begin{array}{c}9(75.0) \\
3(25.0) \\
0\end{array}$ & $\begin{array}{c}63(77.8) \\
18(22.2) \\
3(3.7) \\
\end{array}$ & $\begin{array}{l}0.888 \\
0.888 \\
0.842 \\
\end{array}$ \\
\hline \multicolumn{4}{|l|}{ Administration of denosumab } \\
\hline $\begin{array}{l}\text { Pre- and postoperative } \\
\text { Neoadjuvant therapy } \\
\text { After surgery }\end{array}$ & $\begin{array}{l}2(16.7) \\
8(66.7) \\
2(16.7) \\
\end{array}$ & $\begin{array}{c}5(6.2) \\
59(72.8) \\
17(21.0) \\
\end{array}$ & $\begin{array}{c}0.484 \\
0.920 \\
1.0\end{array}$ \\
\hline \multicolumn{4}{|l|}{ Localization of tumors } \\
\hline $\begin{array}{l}\text { Spine } \\
\text { Pelvic } \\
\text { Sacrum } \\
\text { Upper limb } \\
\text { Lower limb }\end{array}$ & $\begin{array}{c}1(8.3) \\
0 \\
0 \\
4(33.3) \\
7(58.3)\end{array}$ & $\begin{array}{c}5(6.2) \\
4(4.9) \\
6(7.4) \\
14(17.3) \\
52(64.2)\end{array}$ & $\begin{array}{c}0.729 \\
1.0 \\
0.729 \\
0.357 \\
0.920\end{array}$ \\
\hline \multicolumn{4}{|l|}{ Course of treatment } \\
\hline $\begin{array}{l}\text { Lack of response to denosumab } \\
\text { Recurrence of tumor } \\
\text { Tumor shrinkage } \\
\text { Tumor free } \\
\text { Lung metastases }\end{array}$ & $\begin{array}{c}5(41.7) \\
7(58.3) \\
0 \\
0 \\
0 \\
\end{array}$ & $\begin{array}{c}0 \\
0 \\
47(58.0) \\
32(39.5) \\
3(3.7) \\
\end{array}$ & $\begin{array}{c}<< \\
0.0001 \\
< \\
0.0001 \\
0.0006 \\
0.018 \\
0.842 \\
\end{array}$ \\
\hline \multicolumn{4}{|l|}{ Outcome of treatment } \\
\hline $\begin{array}{l}\text { Response to denosumab } \\
\text { Failure to denosumab } \\
\text { Loss of evaluation }\end{array}$ & $\begin{array}{c}0 \\
12(100) \\
0\end{array}$ & $\begin{array}{c}79(97.5) \\
0 \\
2(2.5)\end{array}$ & $\begin{array}{c}<< \\
0.0001 \\
< \\
0.0001 \\
0.603\end{array}$ \\
\hline \multirow[t]{2}{*}{ Case reports, year } & von Borstel et al. (2017) & Satcher et al. (2017) & \\
\hline & $\begin{array}{l}\text { Tsukamoto et al. (2017) } \\
\text { Matcuk et al. (2015) }\end{array}$ & $\begin{array}{c}\text { Yonezawa et al. (2017) } \\
\text { Bardakhchyan et al. (2017) } \\
\text { Menon et al. (2016) } \\
\text { Inoue et al. (2016) } \\
\text { de Carvalho et al. (2016) } \\
\text { Yamagishi et al. (2016) } \\
\text { Kajiwara et al. (2016) } \\
\text { Nakazawa et al. (2016) } \\
\text { Setsu et al. (2016) } \\
\text { Aponte-Tinao et al. (2015) } \\
\text { Park et al. (2015) } \\
\text { Vaishya et al. (2015) } \\
\text { Gossai et al. (2015) } \\
\text { Watanabe et al. (2014) }\end{array}$ & \\
\hline
\end{tabular}




\begin{tabular}{|c|c|c|c|}
\hline $\begin{array}{l}\text { Total number of patients } \\
\text { Male/female } \\
\text { Mean age } \pm \text { SD years }\end{array}$ & $\begin{array}{c}3(100) \\
1(33.3) / 2(66.7) \\
27 \pm 2\end{array}$ & $\begin{array}{c}\text { Mattei et al. (2014) } \\
\text { Hakozaki et al. (2014) } \\
\text { Aghaloo et al. (2014) } \\
\text { Rossi et al. (2014) } \\
\text { Akaike et al. (2014) } \\
20(100) \\
13(65.0) / 7(35.0) \\
26 \pm 11\end{array}$ & $\begin{array}{l}0.680 \\
0.493\end{array}$ \\
\hline \multicolumn{4}{|l|}{ Treatment with denosumab } \\
\hline $\begin{array}{l}\text { Duration of treatment mean } \pm \text { SD months } \\
\text { Follow-up mean } \pm \text { SD months }\end{array}$ & $\begin{array}{l}11 \pm 10 \\
75 \pm 84\end{array}$ & $\begin{array}{c}14 \pm 9 \\
22 \pm 12 \\
\end{array}$ & $\begin{array}{l}0.409 \\
0.615 \\
\end{array}$ \\
\hline \multicolumn{4}{|l|}{ Classification of tumors } \\
\hline $\begin{array}{l}\text { Primary } \\
\text { Recurrent }\end{array}$ & $\begin{array}{c}0 \\
3(100) \\
\end{array}$ & $\begin{array}{l}16(80.0) \\
4(20.0)\end{array}$ & $\begin{array}{l}0.033 \\
0.033 \\
\end{array}$ \\
\hline \multicolumn{4}{|l|}{ Administration of denosumab } \\
\hline $\begin{array}{l}\text { Pre- and postoperative } \\
\text { Neoadjuvant therapy } \\
\text { After surgery }\end{array}$ & $\begin{array}{c}0 \\
2(66.7) \\
1(33.3) \\
\end{array}$ & $\begin{array}{c}2(10.0) \\
15(75.0) \\
3(15.0) \\
\end{array}$ & $\begin{array}{c}0.597 \\
0.689 \\
1.0 \\
\end{array}$ \\
\hline \multicolumn{4}{|l|}{ Localization of tumors } \\
\hline $\begin{array}{l}\text { Skull } \\
\text { Spine } \\
\text { Pelvic } \\
\text { Sacrum } \\
\text { Upper limb } \\
\text { Lower limb } \\
\text { Lung }\end{array}$ & $\begin{array}{c}0 \\
0 \\
0 \\
1(33.3) \\
2(66.7) \\
0 \\
0\end{array}$ & $\begin{array}{l}2(10.0) \\
5(25.0) \\
1(5.0) \\
5(25.0) \\
2(10.0) \\
6(30.0) \\
1(5.0)\end{array}$ & $\begin{array}{l}0.597 \\
0.823 \\
0.262 \\
0.823 \\
0.110 \\
0.689 \\
0.262\end{array}$ \\
\hline \multicolumn{4}{|l|}{ Course of treatment } \\
\hline $\begin{array}{l}\text { Progression of the tumor } \\
\text { Recurrence of tumor } \\
\text { Tumor shrinkage } \\
\text { Tumor free } \\
\text { Lung metastases } \\
\text { Sarcoma } \\
\text { Death from other cancers }\end{array}$ & $\begin{array}{l}2(66.7) \\
1(33.3) \\
0 \\
0 \\
1(33.3) \\
1(33.3) \\
1(33.3) \\
\end{array}$ & $\begin{array}{c}0 \\
0 \\
10(50.0) \\
10(50.0) \\
0 \\
1(5.0) \\
0 \\
\end{array}$ & $\begin{array}{l}0.007 \\
0.262 \\
0.315 \\
0.315 \\
0.262 \\
0.597 \\
0.262 \\
\end{array}$ \\
\hline \multicolumn{4}{|l|}{ Outcome of treatment } \\
\hline $\begin{array}{l}\text { Response to denosumab } \\
\text { Failure of denosumab }\end{array}$ & $\begin{array}{c}0 \\
3(100)\end{array}$ & $\begin{array}{c}20(100) \\
0\end{array}$ & $\begin{array}{l}0.0001 \\
0.0001\end{array}$ \\
\hline
\end{tabular}

Note. SD: Standard deviation; Significant $P$ value in bold

Table 3 Adverse events with the use of denosumab for treatment in patients with giant cell bone tumors divided across open-label phase II studies, case series, and case reports 


\begin{tabular}{l|ccc}
\hline \multicolumn{1}{c|}{ Side effects of denosumab } & Cohort 1 & Cohort 2 & $P$ value \\
& $(\%)$ & $(\%)$ & \\
\hline Open-label phase II studies, no. of patients & $19(100)$ & $215(100)$ \\
\hline Osteonecrosis of the jaw & $5(26.3)$ & $2(0.9)$ & $<0.0001$ \\
Pathological bone fracture & 0 & $2(0.9)$ & 0.380 \\
Peripheral neuropathy & 0 & $6(2.8)$ & 1.0 \\
Skin rash & 0 & $5(2.3)$ & 0.888 \\
Hypophosphatemia & 0 & $2(0.9)$ & 0.380 \\
\hline Case series, no. of patients & $12(100)$ & $\mathbf{8 1 ( 1 0 0 )}$ \\
\hline Pain in the limbs & 0 & $12(14.8)$ & 0.332 \\
Fatigue & 0 & $12(14.8)$ & 0.332 \\
Pathological bone fracture & 0 & $6(7.4)$ & 0.729 \\
Headache & 0 & $6(7.4)$ & 0.729 \\
Serious adverse events & 0 & $6(7.4)$ & 0.729 \\
Hypocalcemia & 0 & $3(3.7)$ & 0.842 \\
\hline Case reports, no. of patients & $3(100)$ & $20(100)$ \\
\hline Osteonecrosis of the jaw & 0 & $1(5.0)$ & 0.262 \\
Back pain & $1(33.3)$ & 0 & 0.262 \\
Hypocalcemia & 0 & $2(10.0)$ & 0.597 \\
Hypophosphatemia & 0 & $1(5.0)$ & 0.262 \\
Hypercalcemia & 0 & $2(10.0)$ & 0.597 \\
Hyperparathyroidism & 0 & $1(5.0)$ & 0.262 \\
Parathyroid adenoma & 0 & $1(5.0)$ & 0.262 \\
\hline
\end{tabular}

Note. Significant $P$ value in bold

Table 4 Type of surgical treatment and embolization of patients with giant cell bone tumors divided across openlabel phase II studies, case series, and case reports 


\begin{tabular}{l|ccc}
\hline \multicolumn{1}{c|}{ Surgery procedures } & Cohort 1 & Cohort 2 & $P$ value \\
& $(\%)$ & $(\%)$ & \\
\hline Open-label phase II studies, no. of patients & $19(100)$ & $215(100)$ \\
\hline Unclear resection & $5(26.3)$ & $153(71.2)$ & 0.0002 \\
No surgery & $14(73.7)$ & $62(28.8)$ & 0.0002 \\
\hline Case series, no. of patients & $12(100)$ & $81(100)$ & \\
\hline Curettage & $7(58.3)$ & $55(67.9)$ & 0.740 \\
En bloc resection & $4(33.3)$ & $14(17.3)$ & 0.357 \\
Joint or prosthesis replacement & 0 & $5(6.2)$ & 0.842 \\
Marginal excision & $1(8.3)$ & $2(2.5)$ & 0.852 \\
Spondylectomy & 0 & $1(1.2)$ & 0.266 \\
No surgery & 0 & $4(4.9)$ & 0.729 \\
\hline Other therapeutic methods & \multicolumn{3}{|c}{} \\
\hline Embolization & $1(8.3)$ & $6(7.4)$ & 0.639 \\
\hline Case reports, no. of patients & $3(100)$ & $20(100)$ \\
\hline Curettage & 0 & $5(25.0)$ & 0.823 \\
En bloc resection & 0 & $3(15.0)$ & 0.842 \\
Joint or prosthesis replacement & $1(33.3)$ & $3(15.0)$ & 1.0 \\
Amputation & $1(33.3)$ & $1(5.0)$ & 0.597 \\
Spondylectomy & 0 & $2(10.0)$ & 0.597 \\
Post-curettage & $1(33.3)$ & 0 & 0.262 \\
Post-incomplete surgical resection & 0 & $1(5.0)$ & 0.262 \\
No surgery & 0 & $5(25.0)$ & 0.823 \\
\hline Other therapeutic methods & \multicolumn{3}{|c}{} \\
\hline Embolization & $2(66.7)$ & $3(15.0)$ & 0.203
\end{tabular}




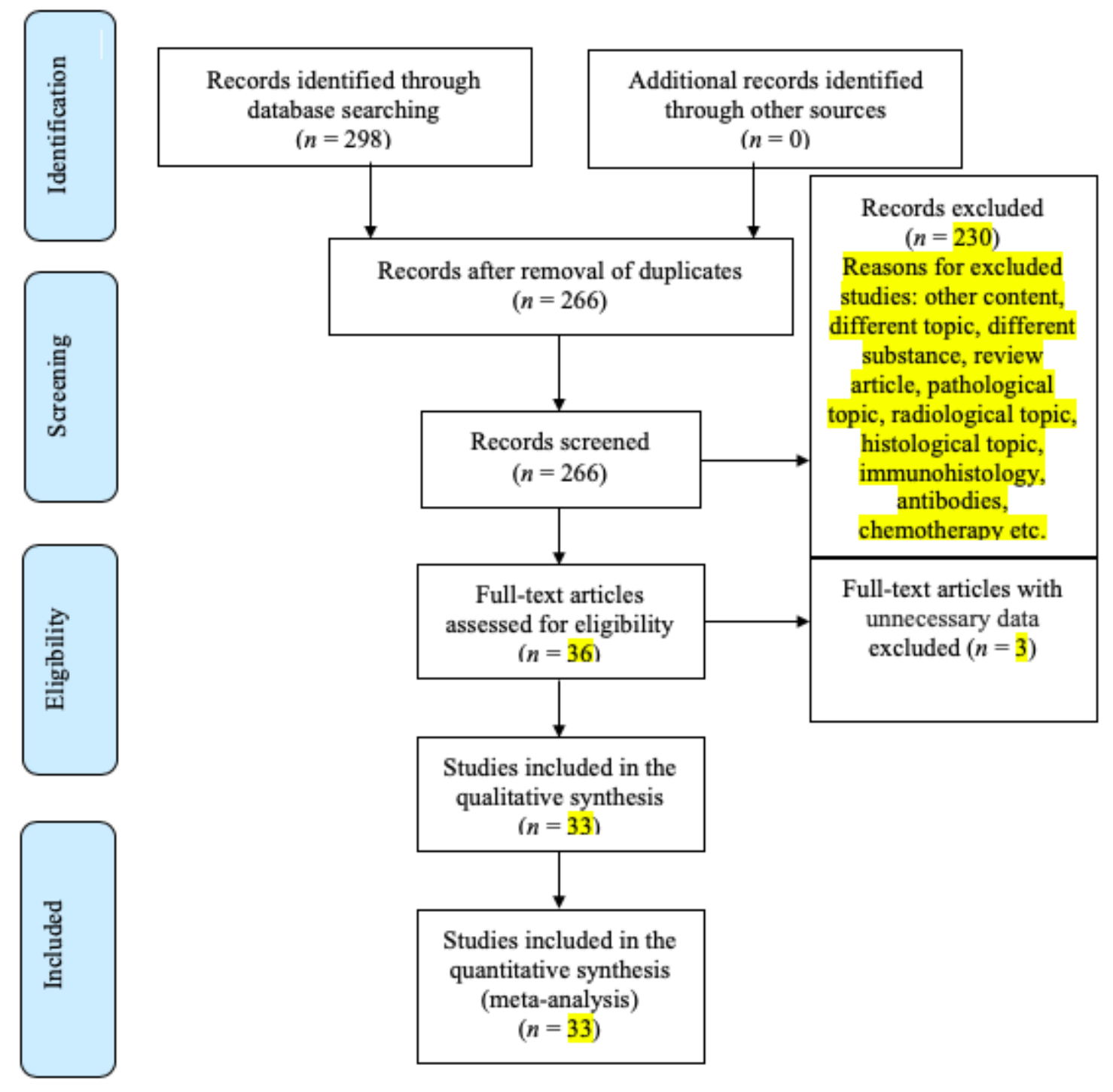

Figure 1

PRISMA (Preferred Reporting Items for Systematic Reviews and Meta-Analyses) 2009 flow diagram for the data collection after the search for suitable studies. 


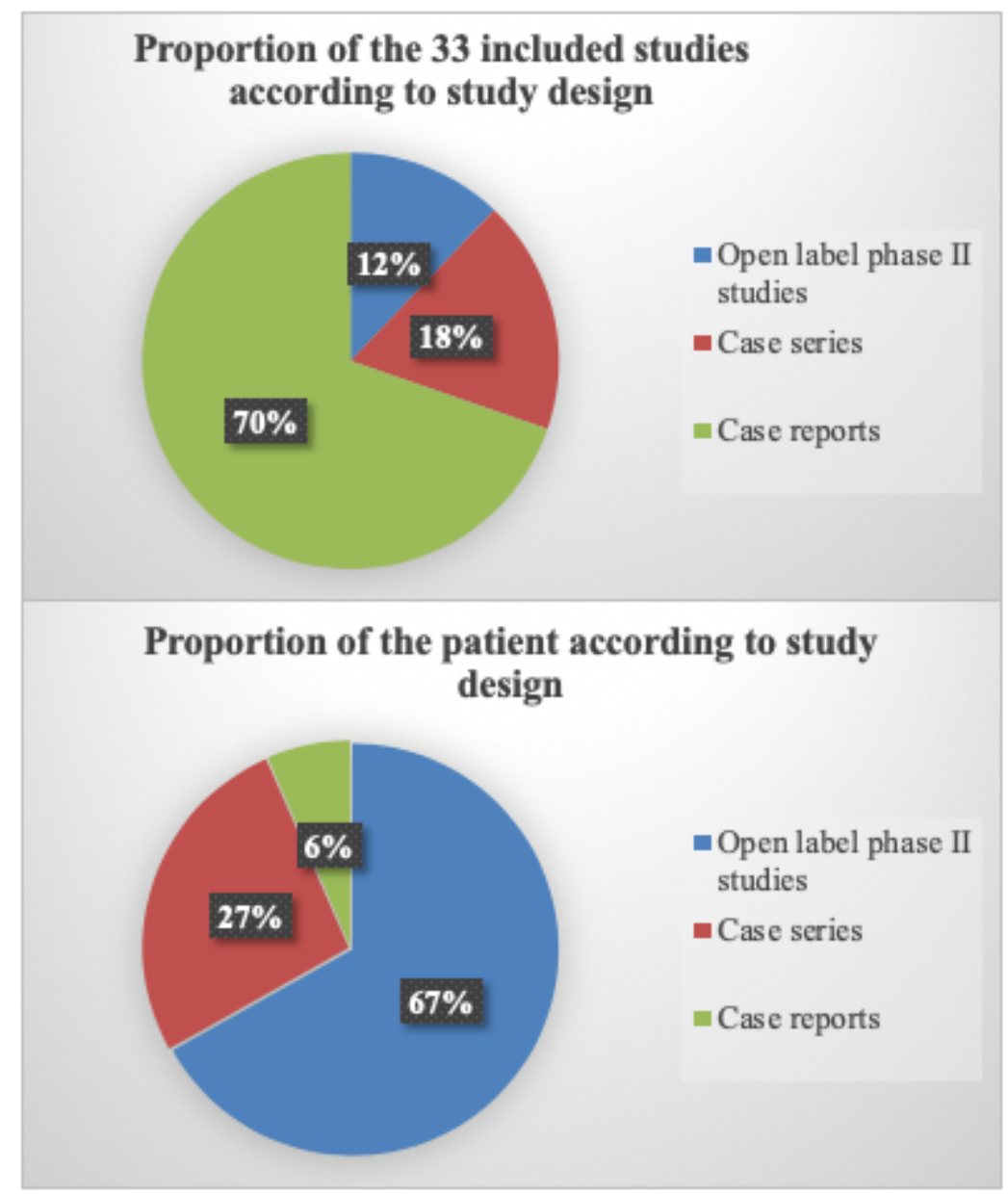

Figure 2

Classification of studies examined for this systematic review according to their study type. 


\begin{tabular}{|c|c|c|c|c|c|c|}
\hline Study & $\begin{array}{c}\text { Question } \\
1 \\
\end{array}$ & $\begin{array}{c}\text { Question } \\
2\end{array}$ & $\begin{array}{c}\text { Question } \\
3 \\
\end{array}$ & $\begin{array}{c}\text { Question } \\
4 \\
\end{array}$ & $\begin{array}{c}\text { Question } \\
5 \\
\end{array}$ & $\begin{array}{c}\text { Question } \\
6 \\
\end{array}$ \\
\hline $\begin{array}{c}\text { Palmerini et al. } \\
\text { (2017) }\end{array}$ & & & & & & \\
\hline $\begin{array}{c}\text { Branstetter et al. } \\
(2012)\end{array}$ & & & & & & \\
\hline $\begin{array}{l}\text { Chawla et al. } \\
\text { (2013) }\end{array}$ & & & & & & \\
\hline $\begin{array}{c}\text { Thomas et al. } \\
(2010)\end{array}$ & & & & & & \\
\hline
\end{tabular}

Key. Low risk of bias: High risk of bias: Unclear risk of bias: ?

\section{Quality assessment tool for open-label studies}

Selection bias caused by inadequate.

Selection bias caused by inadequate.

Performance bias caused by inadequate.

Detection bias caused by inadequate.

Attrition bias caused by inadequate.

Reporting bias caused by selective.

$$
\begin{array}{llllll}
0 \% & 20 \% & 40 \% & 60 \% & 80 \% & 100 \%
\end{array}
$$

घhow risk of bias $\quad$ High risk of bias $\quad$ Unclear risk of bias

\section{Figure 3}

Quality assessment tool for non-randomized, uncontrolled, open-label phase II studies. Question 1 Selection bias caused by inadequate selection of participants. Question 2 Selection bias caused by inadequate confirmation and consideration of confounding variables. Question 3 Performance bias caused by inadequate measurements of intervention. Question 4 Detection bias caused by inadequate blinding of outcome assessment. Question 5 Attrition bias caused by inadequate handling of incomplete outcome data. Question 6 Reporting bias caused by selective outcome reporting. 


\begin{tabular}{|c|c|c|c|c|c|c|c|c|c|c|}
\hline Study & $\begin{array}{c}\text { Quest } \\
\text { ion 1 }\end{array}$ & $\begin{array}{l}\text { Quest } \\
\text { ion 2 }\end{array}$ & $\begin{array}{c}\text { Quest } \\
\text { ion 3 }\end{array}$ & $\begin{array}{c}\text { Quest } \\
\text { ion 4 }\end{array}$ & $\begin{array}{c}\text { Quest } \\
\text { ion 5 }\end{array}$ & $\begin{array}{c}\text { Quest } \\
\text { ion 6 }\end{array}$ & $\begin{array}{l}\text { Quest } \\
\text { ion 7 }\end{array}$ & $\begin{array}{c}\text { Quest } \\
\text { ion 8 }\end{array}$ & $\begin{array}{c}\text { Quest } \\
\text { ion 9 }\end{array}$ & $\begin{array}{c}\text { Quest } \\
\text { ion } \\
\text { 10 }\end{array}$ \\
\hline $\begin{array}{c}\text { Ji et al. } \\
(2017)\end{array}$ & + & + & + & + & + & + & + & + & + & $?$ \\
\hline $\begin{array}{c}\text { Deveci } \\
\text { et al. } \\
(2017)\end{array}$ & + & + & + & + & + & + & + & + & + & + \\
\hline $\begin{array}{c}\text { Rekhi et } \\
\text { al. } \\
(2017)\end{array}$ & + & + & + & + & X & + & + & + & + & X \\
\hline $\begin{array}{c}\text { Müller } \\
\text { et al. } \\
(2016)\end{array}$ & + & + & + & + & + & + & + & + & + & X \\
\hline $\begin{array}{c}\text { Traub et } \\
\text { al. } \\
(2016)\end{array}$ & + & + & + & + & + & + & + & + & + & + \\
\hline $\begin{array}{l}\text { Goldsch } \\
\text { lager et } \\
\text { al. } \\
(2015)\end{array}$ & + & + & + & + & + & + & + & + & + & $?$ \\
\hline
\end{tabular}

Key. Yes; Low risk of bias: No; High risk of bias: Unclear risk of bias:

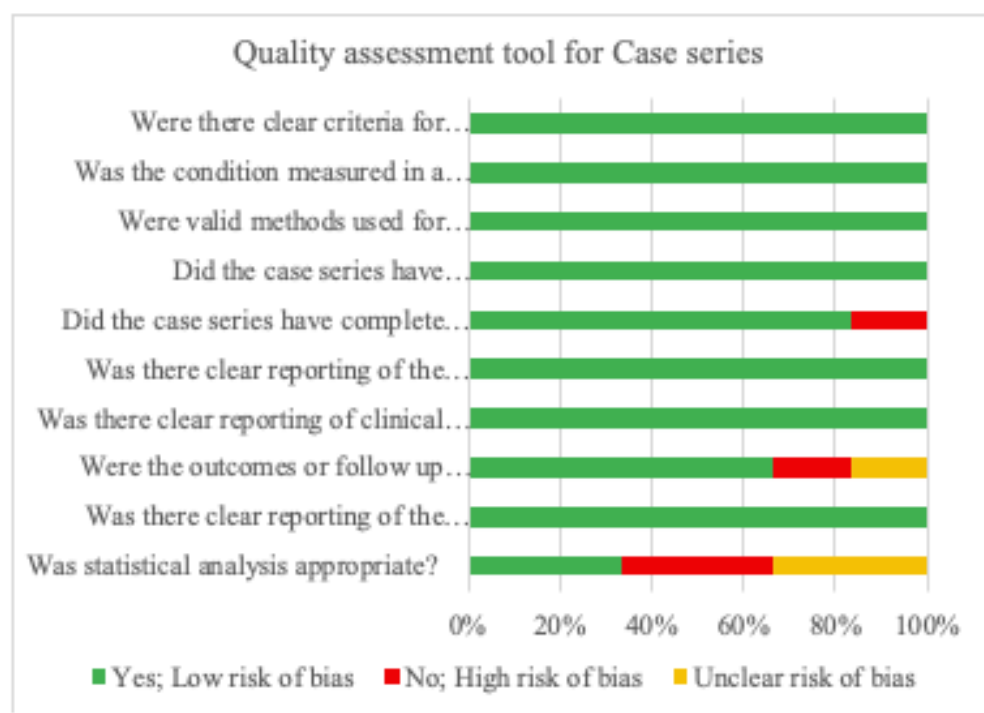

\section{Figure 4}

Quality assessment tool for case series. Question 1 Were there clear inclusion criteria for the case series? Question 2 Was the condition measured in a standard, reliable way for all the participants of the case series? Question 3 Were valid methods used for the identification of the participants' condition? Question 4 Did the case series have a consecutive inclusion of participants? Question 5 Did the case series have a complete inclusion of participants? Question 6 Was there clear reporting of the participants' demographics? Question 7 Was there clear reporting of the participants' clinical information? Question 8 Were the outcomes or follow-up results of cases clearly reported? Question 9 Was there clear reporting of the demographic information of the presenting clinics? Question 10 Was the statistical analysis conducted appropriately? 

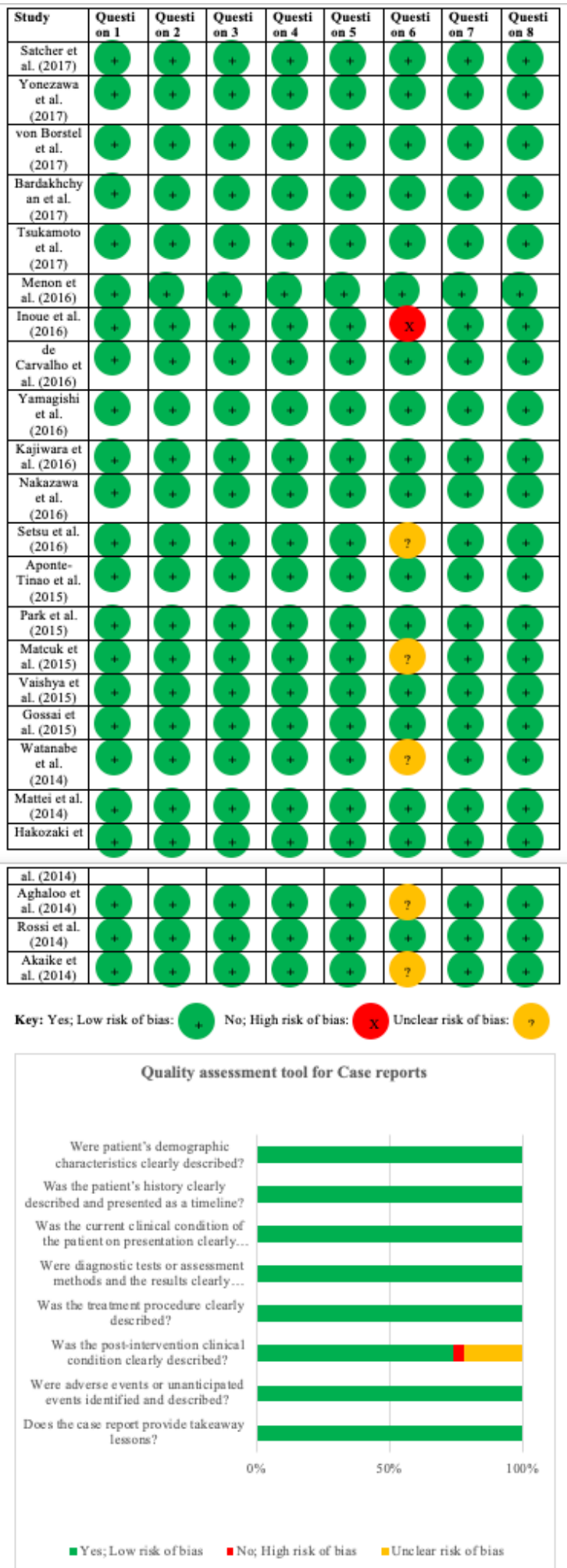

\section{Figure 5}

Quality assessment tool for case reports. Question 1 Were the patients' demographic characteristics clearly described? Question 2 Was each patient's history clearly described and presented as a timeline? Question 3 Was the current clinical condition of the patients on presentation clearly described? Question 4 Were diagnostic tests or assessment methods and the results clearly described? Question 5 Was the treatment procedure clearly described? Question 6 Was the post-intervention clinical condition clearly 
described? Question 7 Were adverse events or unanticipated events identified and described? Question 8 Does the case report provide any takeaway lessons? 